\title{
Patriotic Name Bias and Stock Returns
}

\author{
Evangelos Benos and Marek Jochec* \\ September 1, 2011
}

\begin{abstract}
Companies whose names contain the words "America(n)" or "USA" earn positive abnormal returns of about 6\% per annum during the Second World War, the War in Korea and the War on Terror. These abnormal returns are not realized immediately upon the outbreak of each of the wars but are accumulated gradually during wartime. Given that no such effect is observed for the Vietnam War, we hypothesize that major, victorious wars arouse investors' patriotic feelings and cause them to gradually and perhaps subconsciously gravitate toward stocks whose name has a patriotic flavor.
\end{abstract}

\section{Introduction}

Consumers' and investors' patriotic feelings have been shown to affect their economic behavior. The academic literature in business and marketing, for instance, has documented a positive relationship between patriotism and consumer propensity to purchase domestic goods (Shankarmahesh, 2006). In financial markets too, there is evidence suggesting that patriotism is an important determinant of investor behavior. In an attempt to tap investors' patriotic sentiment and at the same time finance the war effort, the US government issued "Liberty Bonds" during WWI, "War Bonds" during WWII while more recently, the "Freedom Bonds Act" of 2001 enabled the Treasury to issue "Patriot Bonds" to help finance the War on Terror. These attempts to raise money were very successful: the WWII Series E "War Bond" issue raised about $\$ 185.7$ billion, contributed to by around 85 million Americans, ${ }^{1}$ while following the September 11 terrorist attacks, the sales of Series I and EE Treasury Bonds that were renamed "Patriot Bonds", rose by 43\% (Sulon, 2001).

\footnotetext{
${ }^{*}$ Corresponding author; This work was primarily completed while the authors were at the University of Illinois at Urbana-Champaign. They can be reached at evangelosb@gmail.com and marek.jochec@iscte.pt respectively. We would like to thank Steven Beach, Neil Pearson, Josh Pollet, Pedro Santa-Clara and seminar participants at Bangor Business School, the Bank of England, Rouen Business School, the University of Illinois, the University of Leicester, Stirling University and participants of the 2009 MFA conference in Chicago for helpful comments and suggestions. We would also like to thank the University of Leicester for research support. All errors are ours.

${ }^{1}$ See the "Brief History of World War Two Advertising Campaigns, War Loans and Bonds" for more details, accessible at http://library.duke.edu/digitalcollections/adaccess/warbonds.html. A more detailed reference, is Kimble (2006).
} 
Recent research has also shown that patriotism can influence investor behavior in a more systematic way and not only during war periods. In a sample of 53 countries, Morse and Shive (2011) find that measures of patriotism are positively related to the level of home equity bias, controlling for transaction costs, information acquisition costs, diversification benefits and investor familiarity with their home country.

On a different, but related to our paper, research front, finance scholars have also examined the effect of a company's name on investor behavior and firm value. Most of the focus in the related literature has been on the stock price effect of a corporate name change. Despite anecdotal evidence that company name changes add value to firms, earlier studies have found that in general such effects are economically insignificant, that they are not associated with increased earnings and that they are either sample-specific or they are influenced by outliers [Karpoff and Rankine (1994) and Bosch and Hirschey (1989)]. It seems however, that specific name changes at specific times do matter. In a more recent event study, Dimitrov and Rau (2001) show that companies which changed their name to include ".com" between June 1998 and July 1999 (i.e. during the "tech bubble") earned cumulative abnormal returns of about $74 \%$ in a ten-day window around the name-change announcement. Furthermore, this effect did not seem to be transitory as the authors failed to detect a post-name-change announcement negative drift.

Both patriotism-induced investor behavior and corporate name changes are linked to the concept of market efficiency. One of the empirical implications of market efficiency is that prices should not react to the absence of information about the traded securities ${ }^{2}$. Thus, in an efficient market, investors' level of patriotism should be orthogonal to stock prices either because investors act rationally and are not influenced by sentiment, or in case they do, any resulting mispricing is arbitraged away. Similarly, if a corporate name change does not add information about a company, it should not be priced. Also, viewed as firm characteristic, corporate names should have no effect on the cross-section of stock returns because they are not a source of risk.

Our paper tests the joint hypothesis that patriotism and corporate names have an impact on the cross-section of stock returns. To do that, we look at the returns of stocks with patriotic sounding names, ${ }^{3}$ at times when peoples' patriotic sentiment is likely to be high. In our case such periods are assumed to be those of the four largest (and costliest) wars that the US fought in the second half of the 20th century, namely World War II (WWII), the War in Korea, the Vietnam War and the War on Terror. Our goal then is to examine if at times when patriotic sentiment is likely to be high, investors view stocks with patriotic names differently than stocks with no patriotic names but with otherwise similar characteristics.

We start our analysis by performing tests that utilize a four-factor asset pricing model. Every month and over multi-year periods around the beginning of each of the wars, we form value-weighted portfolios of stocks with patriotic names. We then regress the returns of these portfolios on the standard Fama-French-Carhart risk factors, with the variable of interest being alpha (the intercept). We find that stocks with patriotic names generally earn positive abnormal returns during WWII, the War in Korea and the War on Terror but not during the Vietnam War. Additionally, we detect no abnormal returns immediately before

\footnotetext{
${ }^{2}$ Shiller $(1981)$ and Roll $(1984,1988)$ are the first studies that directly test this hypothesis.

${ }^{3}$ Specifically, we look at companies whose names contain the words: "America(n)" and/or "US(A)".
} 
the beginning of each of the wars and also during the first six months of WWII. The abnormal returns that we do detect for the duration of the War on Terror, the War in Korea and the bulk of WWII, are as high as $6 \%$ per annum and are thus economically significant. Given that both the Vietnam War and the first six months of WWII are arguably times when investors might not have been positively exuberant about the ongoing war effort, ${ }^{4}$ we interpret our results as evidence that investors tend to gravitate toward stocks with patriotic sounding names and that the market fails to correct the mispricing.

A potential weakness of the factor-model benchmarking approach is that the abnormal returns could be driven by industry effects: Since there are industries (e.g. defence, telecommunications) that tend to perform better during wartime, it could be that these industries also have a higher concentration of firms with patriotic names, thus giving rise to a selection bias. To account for this, we construct control portfolios consisting of stocks that match by industry, size and book-to-market the stocks of the original portfolios, but which have no patriotic sounding names. We then repeat the test using these control portfolios but fail to detect any abnormal returns. We also control for a number of other potential explanations, such as product market exuberance, IPO underpricing and unique risk. Our robustness checks show that our results cannot be attributed to any of these factors.

To get a better idea of when the detected mispricings start to appear and how they evolve over time, we next calculate cumulative abnormal returns (CARs) of portfolios of stocks with patriotic sounding names, for the periods over which the portfolio alphas are positive. As benchmarks we either use the returns of control portfolios that match the patriotic name portfolios by industry, size and book-to-market, or the returns predicted by the market model.

These tests reveal a pattern in the timing of abnormal returns: The stock price reaction of the "patriotic name" portfolios is not immediate, i.e. it is not realized upon the outbreak of each of the wars that we consider. Rather, it is gradual and it takes as much as two years for the stocks with patriotic names to attain their maximum cumulative abnormal return. This finding not only implies that the market cannot quickly correct the mispricing, but it is also suggestive of an investor sentiment model whereby the bias in favor of stocks with patriotic sounding names manifests itself over a long time horizon. This is consistent with investors being gradually (and perhaps subconsciously) attracted to such stocks when faced with a number of stocks to choose from. In other words, our results suggest that investors do not actively seek to invest in companies with patriotic sounding names upon the outbreak of a war; instead, they tend to invest more heavily than otherwise in such stocks, during wartime, whenever they come across them.

Finally, we should remark that not all patriotism-induced investor behavior need be the result of investor sentiment. If investors care about the well-being of their country, they may well choose to invest in a way that is not optimal in terms of the risk and return tradeoff, but is nevertheless good for their country (e.g. by over-weighing their portfolios with domestic stock instead of diversifying internationally). These investors are effectively donating a portion of their wealth to their country. Morse and Shive (2011), who document this effect, mention the example of a central bank head who "understood the benefits of diversification but conveyed to the pension manager that the country needed the capital at

\footnotetext{
${ }^{4}$ We provide some evidence for this in the discussion of the results.
} 
home". The "patriotic name bias" that we document however, cannot be explained by such examples of deliberate patriotic giving, because if investors bought stocks during wartime with the sole purpose of supporting their country's businesses and economy, they would have no reason to concentrate on stocks with patriotic sounding names.

\section{Methodology and Results}

\subsection{Wartime Periods as Proxies for Patriotic Sentiment}

Since we want to see if there is an effect of patriotic sentiment on stock prices, we need a measure of patriotism over time. Unfortunately, such measures are rare and the few existing ones cover only recent and brief periods of time. ${ }^{5}$ The reason then why we choose periods of war for our analysis, is because we think that wars have the potential to significantly arouse people's patriotic feelings. Additionally, the US has fought some major wars over the past fifty years, which means that these wars provide a good opportunity to examine the effect of patriotism on investor behavior.

We use data around the four largest and most dramatic for the United States wars; these are in chronological order: World War II (WWII), the War in Korea, the Vietnam War and the War On Terror that the United States undertook in Afghanistan and Iraq following the terrorist attacks of September 11, 2001. We select these wars because they are the largest in scale and costliest, in terms of casualties and resources consumed, over the time period for which stock price data is available. Large conflicts have profound effects on societies and are thus far more likely to stir peoples' emotions. It is for this reason that we exclude many other smaller-scale conflicts like the invasions in Grenada and Panama, the first Gulf war of 1990-91, etc.

Since direct measures of patriotism over time in the United States are sporadic at best and non-existent at worst, it is in general difficult to provide concrete evidence of how patriotic sentiment was influenced by the aforementioned wars and especially the older ones (WWII, Korea and Vietnam). We however provide evidence that patriotic sentiment increased significantly during the War on Terror. This proves that wars have the potential to increase patriotic sentiment. We should also mention that the Vietnam war stands out because, contrary to the other wars, it was not victorious and is widely perceived to have been the most unpopular conflict of the United States in the 20th century. ${ }^{6}$ For this reason, it is doubtful if and to what extent this war increased patriotic sentiment. We however include this war in our analysis to facilitate comparison with the other wars.

Regarding the War on Terror, the patriotism index in the World Value Survey used by Morse and Shive (2011) confirms the rise in patriotic sentiment after 2001. Also, in a poll of 425 Utah residents that was conducted in October 2001 by Dan Jones \& Associates, $75 \%$ of the respondents said that they "definitely" have a deeper sense of patriotism since

\footnotetext{
${ }^{5}$ For instance, in the World Values Survey, used by Morse and Shive (2011), the US is only included in the years 1982, 1990, 1995, 2000 and 2006.

${ }^{6}$ See for instance the survey results on the popularity of the Vietnam war among Americans reported in Lunch and Sperlich (1979).
} 
the September 11 events. ${ }^{7}$ We also attempt to more accurately and systematically capture patriotic sentiment around September 2001 by looking at the popular press: if patriotic sentiment was indeed higher following 9/11, this must have been reflected in the articles published in the press. For this reason, we use the Nexis database to search for phrases in articles, published before and after $9 / 11$, that are indicative of patriotic sentiment. 8 There is of course a multitude of candidate phrases, so we simply choose to search for the phrases "American patriotism" and "proud of America" (a direct and indirect reference to patriotism respectively), which we think are likely to show up when a patriotic sentiment is prevalent.

Table 1 shows the total number of English language news articles which contain these two phrases and which were written over multiple time horizons before and after September 11, 2001. It is evident that the number of such articles is much larger after September 11 than before, especially over the two-month window around the event. Furthermore, the difference in frequencies persists for at least four years after the event. To eliminate the possibility that this difference in frequencies is because of the natural increase, over time, in the total number of articles covered by Nexis, we fit a second degree polynomial trendline for the 1975-2001 period and use this trend to predict article frequencies after 2001. These results appear in Figure 1. Actual article frequencies are clearly much larger than predicted frequencies for both phrases. ${ }^{9}$ We interpret this as evidence of patriotic exuberance following the September 11 attacks.

\subsection{Data and Summary Statistics}

Stock names, returns and market sizes are from CRSP, the book-to-market ratios and industry codes are from the merged CRSP/Compustat database while the risk factors used in our regressions are from the website of Kenneth French. ${ }^{10}$ From the universe of stocks in CRSP we keep only those which have a share code equal to 10 or 11 i.e. we exclude ADRs, REITs, closed-end funds etc. We also exclude any stocks with missing values for returns, prices, company identification number or number of shares outstanding. For one of our robustness checks we also use quarterly sales growth data from Compustat. Data on the number and size of trades around September 11, 2001 is from the Trades and Quotes (TAQ) database.

To construct our portfolios, we classify a company's name as patriotic if it contains the words "America(n)" and "US(A)". We only use these two words because they appear frequently enough to allow us to construct portfolios of stocks and thus decrease the possibility that our results are driven by idiosyncratic risk. We restrict ourselves to these two words so as to avoid having to arbitrarily decide whether a given name is patriotic or not. We also exclude any companies where the word "American" or "US" in their name is not exclusively related

\footnotetext{
${ }^{7}$ Source: Deseret Morning News/KSL-TV, 2006.

${ }^{8}$ Nexis allows one to search for a phrase in the popular press, published anytime since the mid-late 70's. For a given search phrase, date range and media source, we obtain the number of articles that contain one or more instances of the search phrase. Unfortunately, the Nexis data range does not allow us to use the database for the same purpose for WWII, the War in Korea and the Vietnam War.

${ }^{9}$ The large number of articles containing the phrase "proud of America" in late 2007 and 2008 is because of the frequent use of this phrase during the Obama-McCain presidential election campaign.

${ }^{10} \mathrm{http}: / /$ mba.tuck.dartmouth.edu/pages/faculty/ken.french/data_library.html
} 
Table 1: Number of articles in the "All English Language News" category of the Nexis database containing one or more instance of the phrases "American patriotism" (Panel A) and "proud of America" (Panel B) for different time windows around September 11, 2001.

\begin{tabular}{|c|c|c|c|}
\hline Time window & before $9 / 2001$ & after $9 / 2001$ & after/before ratio \\
\hline Panel A & \multicolumn{3}{|c|}{ "American patriotism" } \\
\hline 10 days & 5 & 95 & 19.0 \\
\hline 30 days & 10 & 235 & 23.5 \\
\hline 90 days & 68 & 443 & 6.5 \\
\hline 180 days & 141 & 715 & 5.1 \\
\hline 1 year & 203 & 1083 & 5.3 \\
\hline 2 years & 318 & 1520 & 4.8 \\
\hline 3 years & 423 & 1949 & 4.6 \\
\hline 4 years & 516 & 2171 & 4.2 \\
\hline Panel B & \multicolumn{3}{|c|}{ "proud of America" } \\
\hline 10 days & 0 & 24 & - \\
\hline 30 days & 0 & 49 & - \\
\hline 90 days & 9 & 102 & 11.3 \\
\hline 180 days & 14 & 143 & 10.2 \\
\hline 1 year & 53 & 232 & 4.4 \\
\hline 2 years & 172 & 377 & 2.2 \\
\hline 3 years & 229 & 710 & 3.1 \\
\hline 4 years & 303 & 816 & 2.7 \\
\hline
\end{tabular}

to the United States. Table 2 lists some examples of company names that are excluded, along with the reason for excluding them.

Table 2: Examples of company names that contain the words "American" or "US" but are excluded from our sample and the reason of exclusion.

Company Name

MID AMERICAN WASTE SYSTEMS INC LATIN AMERICAN CASINOS INC GERMAN AMERICAN BANCORP TOYS R US INC
Reason for exclusion

Name is related to a region within the US Name is related to a foreign region Name does not exclusively refer to the US "US" is used here as a pronoun

For the asset pricing regressions, we classify firms' names as patriotic, every month, for the duration of each of the wars and for a maximum period of 48 months immediately before 
each of the wars broke out. Table 3 shows size and book-to-market summary statistics of patriotic stocks averaged over 48 months, during and before WWII, the War in Korea and the War on Terror. ${ }^{11}$ One thing to notice is that the size distribution is clearly more skewed for the firms with patriotic names as the distances between mean and median size indicate; our patriotic portfolios evidently contain few large stocks that drive size statistics. This is the reason why in our robustness tests we also use equally weighted portfolios .

Table 3: Size and Book-to-Market summary statistics of stock portfolios with patriotic names and of the CRSP universe (numbers in parentheses). For WWII, the War in Korea and the War on Terror, we report the average number of patriotic stocks in our portfolios and size and book-to-market statistics for the duration of the war (During) and a 48 month period immediately before the war (Before). Size statistics are in millions of dollars. Book-to-market statistics for the WWII and the Korean war are not available because Compustat started reporting book value of equity figures in 1962.

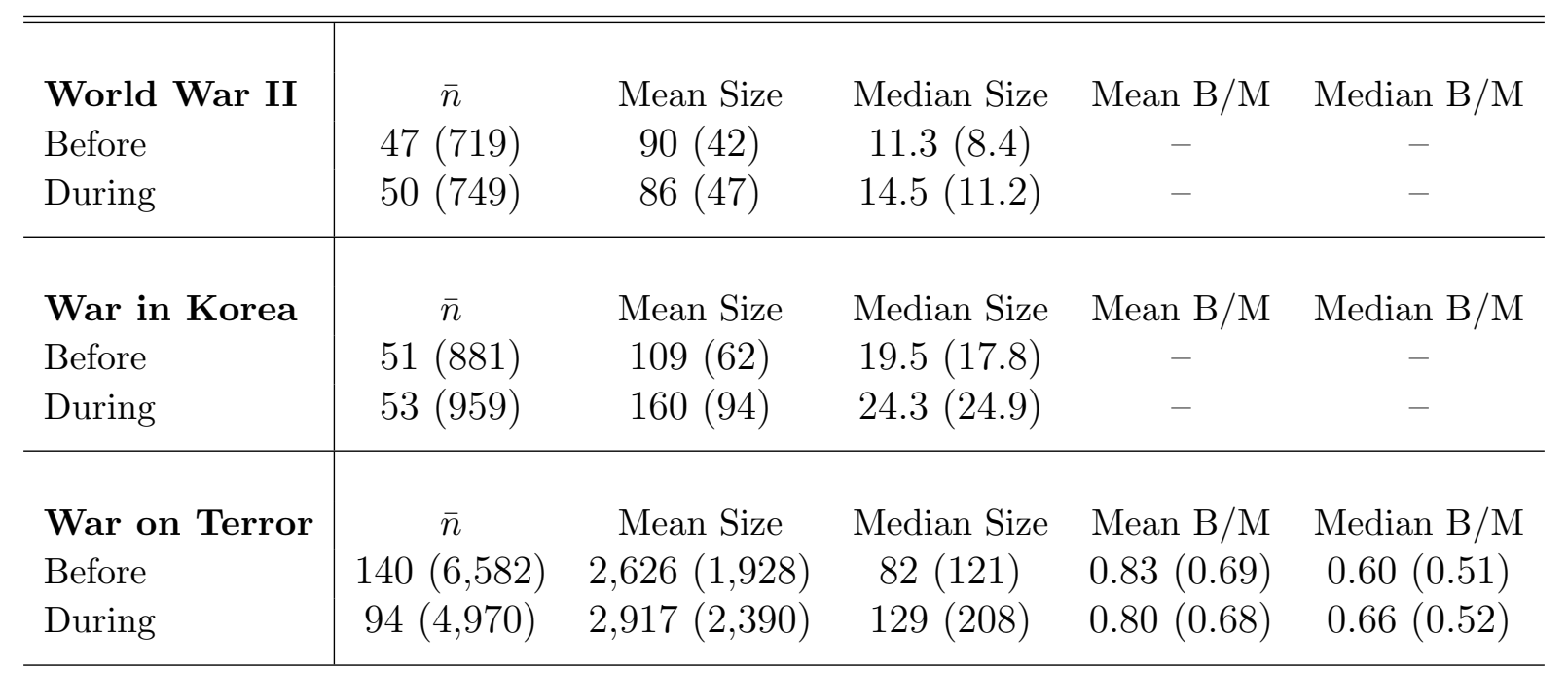

\section{$2.3 \quad$ Fama-French Regressions}

To examine whether patriotic stocks earn abnormal returns during wartime, we use the four factor Fama-French model for the purpose of benchmarking. This involves regressing monthly returns of value-weighted patriotic stock portfolios on the monthly values of four risk factors that have been shown to have explanatory power on stock returns. These factors are the original three in Fama and French (1993, 1995, 1996) namely, market premium, HML and SMB as well as the Carhart (1997) momentum factor constructed to take into account the momentum effect described in Jegadeesh and Titman (1993). Thus, the empirical specification is:

$$
R_{p t}-r_{f t}=\alpha+\beta\left(R_{m t}-r_{f t}\right)+\gamma S M B_{t}+\delta H M L_{t}+\zeta M O M_{t}+\epsilon_{t}
$$

\footnotetext{
${ }^{11}$ Because there are multiple candidate dates for the beginning of the Vietnam War and to conserve space, we do not report size and book-to-market statistics of "patriotic" name stock portfolios around each of the candidate dates for this war. These statistics are available upon request.
} 
For all regressions, we estimate the risk factor coefficients using the Heteroscedasticity and Autocorrelation (HAC) consistent estimator suggested by Newey and West (1987). Tests of serial correlation point to the use of one lag for this estimator.

The hypothesis we want to test is whether there is a patriotic name effect at times of heightened patriotic excitement. For this reason, we estimate model (1) using monthly data over multi-year periods after each of the wars broke out. We also estimate model (1) over multi-year periods before the beginning of each war, to facilitate comparison with the war periods.

Tables 4 to 7 show the estimated coefficients of model (1) over two, three and four-year periods before and after the beginning of each war and also coefficients estimated up until the end of the war for those wars that lasted less than four years. The war starting dates that we use are December 7, 1941 (attack on Pearl Harbor) for WWII, June 25, 1950 (start of full scale hostilities) for the War in Korea, August 7, 1964 (congress authorization of use of force) for the War in Vietnam and September 11, 2001 (attack on World Trade Center) for the War on Terror. In these regressions we only report results for value-weighted portfolios since these are economically more meaningful.

The results from these regressions show no statistical significance for Carhart's alpha before the beginning of any of the war periods, regardless of whether model (1) is estimated over two-, three- or four-year periods. Patriotic stock portfolios do exhibit abnormal returns over multiple periods after 9/2001 and over a four year period after the beginning of the War in Korea. The alphas estimated during the War on Terror are very significant (at 5\% and 1\% levels) for all time periods while the ones from the Korean War are gradually increasing in significance and become significant at $5 \%$ when estimated over a four-year period after the beginning of that war. On the other hand, no abnormal returns are detected for the duration of WWII and the Vietnam War. We therefore next explore stock returns during these two wars in more detail.

One problem with the Vietnam war is that the date that marks its beginning is not as clear as is the case with the other wars. The US involvement in Vietnam was gradual and spanned a long period of time; the August 1964 date we used for our regressions is one of many alternative candidate dates that marked various levels of US involvement. ${ }^{12}$ Therefore, the lack of any abnormal returns could be because we have selected a wrong reference date. For this reason we estimate again model (1) for all overlapping four-year periods between 1950 and 1978, a time frame which includes all the events related to the Vietnam War. For these regressions the beginning month is the January of each year.

The estimated intercepts along with their t-statistics are shown in Table 8 where we also provide for the purpose of comparison the dates and brief descriptions of some events that have been cited as potential candidates for marking the beginning of the Vietnam War. All of the alphas (with the exception of one) are insignificant suggesting that there is no "patriotic name bias". ${ }^{13}$ We suspect that the lack of a "patriotic name bias" during the Vietnam War

\footnotetext{
${ }^{12}$ Such alternative dates include the arrival of US military advisors in the area, their first engagement in combat, the first conflicts after the official approval to use military force, etc.

${ }^{13}$ It is interesting however that all the negative alphas are concentrated in the late sixties and early seventies, a period that roughly corresponds to the time of least popularity for the war, at least as evidenced by the poll results in Lunch and Sperlich (1979). The mean of these alphas is significantly different (at 1\%) from the alphas calculated in the fifties and mid to late seventies.
} 
could be because this war was generally unpopular with the public and/or because it was not victorious.

If this is intuition is correct, then perhaps there might be a "patriotic name bias" during subperiods of WWII when the public was more optimistic about the outcome of the war. Such subperiods must exist during WWII since the war started with a devastating surprise attack against the US and ended with an overwhelming US victory. In trying to identify such subperiods, we note that following the Pearl Harbor attack and until the battle of Midway in June 1942, Japan seemed to have the upper hand in the Pacific conflict and the outcome of the war was at the time completely uncertain. Pearl Harbor was followed by more setbacks for the US in the worst case and no significant hostilities in the best. ${ }^{14}$ Midway was the first American victory against Japan and the "turning point" ${ }^{15}$ of the battle in the Pacific. We therefore estimate again model (1) over multiple periods after the battle of Midway (i.e. excluding the first six months of the war) and until the end of the war. These results appear in table 9 . All intercepts are now statistically significant at $5 \%$ levels.

In Table 10 we combine all pre-war and wartime periods so as to assess the economic significance of the "patriotic name bias". Here, model (1) is estimated over the combined four-year wartime and pre-war periods, excluding Vietnam and the first six months of WWII. For the combined wartime periods, alpha is economically significant at 0.005 . This means that a patriotic-name stock portfolio earns a risk-adjusted $0.5 \%$ excess return on a monthly basis, or about $6 \%$ per annum.

\subsubsection{Discussion of the Fama-French regression results}

The results so far provide evidence of a "patriotic name bias" in stocks. The underlying hypothesis is that wars can cause investors' patriotic sentiment to rise and as a result investors gravitate toward stocks whose name has a patriotic sounding name. The significant wartime alphas and the absence of any significance before the wars suggests that during wartime investors view stocks with patriotic sounding names differently. The fact that the Vietnam War and the first six months of WWII produce no alphas, further suggests that it must be patriotic exuberance and enthusiasm that actually cause investors to gravitate toward these stocks. As we mentioned already, the Vietnam war was the most unpopular military engagement of the US in the 20th century while the first six months of WWII were marked by enemy successes in the war theater and thus offered little excuse for exuberance. The absence of significant alphas during these periods confirms then the intuition that for a patriotic name bias in stocks to materialize, investors must be significantly and positively excited about the prospects of their country's war effort.

The estimated alphas during the War on Terror (in Table 7) are also consistent with this intuition. The War on Terror was initially marked by military victories in Afghanistan and Iraq and it was not until three to four years after the beginning of the war (i.e. in 2004-2005) that the insurgency in Iraq and US casualties reached a peak and the mood of the public

\footnotetext{
${ }^{14}$ In the six month period following the attack on Pearl Harbor, the Japanese invaded Burma, the Dutch East Indies, the Solomon islands, Manila and Singapore. The allies were subsequently also defeated at the battle of Java Sea in early March 1942.

${ }^{15}$ Gordon Prange, "Miracle at Midway", (1982)
} 
changed accordingly. Opinion polls at the time suggested that the war's outcome had been deemed more uncertain. ${ }^{16}$. The estimated wartime alphas in Table 7 decline in economic and statistical significance as the war gradually becomes less popular and its outcome becomes less certain. Overall, the fact that a name bias coincides with times when patriotic exuberance was likely to be elevated, is consistent with a behavioral explanation of this market effect.

\subsubsection{Evidence from trade data}

Evidence from trade data ${ }^{17}$ around September 11, 2001 reinforces the argument that the observed abnormal returns are the result of a behavioral bias. In a 48-month period before $9 / 11$, the percentage of trades, worth less than $\$ 5000$ in the sample of all patriotic name stocks, was $56.5 \%$. This percentage climbed to $73.1 \%$ during the 48 months after $9 / 11$. This suggests that the patriotic name effect is primarily driven by retail investors whose behavior is more likely to be driven by patriotic excitement.

\subsection{Robustness Checks}

In this section we do a series of robustness checks to eliminate other potential explanations or systematic biases from which the regression results may suffer. Because book-to-market data is not available on Compustat before 1962, we exclusively use data around the War on Terror for these robustness checks.

\section{Industry effects}

As mentioned before, a concern about the Fama-French regression results is that they may be driven by an industry effect. If firms with patriotic names are concentrated in industries that tend to do well during wartime, then the abnormal returns that we see may be due to increased profitability rather than investor bias. Summary statistics of the industry distribution suggest that this is unlikely. For example only $1.2 \%$ of our firms belong to the two-digit SIC category 37 which includes most defense companies, while the population percentage of the firms in this category is $1.7 \%$.

To more formally test if there is an industry effect however, we match patriotic name stocks with stocks whose name does not contain the words "US(A)" or "America(n)" and compare the performance of the two groups of stocks during the War on Terror. The exact matching procedure is as follows: Every June in an eight-year window around September 2001, and for every stock with a "patriotic" name in our sample, we find another stock which is in the same industry (i.e., has the same four-digit SIC) and has similar book-to-market and

\footnotetext{
${ }^{16}$ The public was supportive of the invasions in Iraq and Afghanistan and of the war conduct for at least the first three years after 9/11. According to a Newsweek poll of about 1,000 adults in February 2004, 65\% of the respondents approved of the government's handling of the war. A poll in July 2007 found that the approval rate had dropped to 43\%. (Source: www.pollingreport.com/terror) This suggests that people may have become more pessimistic about the war's outcome.

${ }^{17}$ The trade data is from the Trades and Quotes (TAQ) database.
} 
size. ${ }^{18}$ We then use these matches to construct every month value-weighted portfolios and we estimate specification (1) over two, three and four-year periods before and after 9/2001.

If the initial regression results were driven by an industry effect, then the match portfolios should exhibit the same positive and significant abnormal returns after 9/2001. However, the results in Table 11 show that they do not. In fact, the alphas of the control portfolio become negative (albeit insignificantly) after 9/2001. As an additional check, we re-estimate model (1) using this time as a dependent variable the difference in returns of the patriotic stocks and their matches. That is, every month we construct a zero-net-investment portfolio by buying the patriotic stock portfolios and shorting their matches. We then regress the monthly returns of this portfolio on the Fama-French-Carhart risk factors. As before, we do this for two, three and four-year periods before and after 9/2001. These results are reported in Table 12. Although only the two-year post $9 / 11$ alpha is statistically significant at $5 \%$, there is a clear pattern: Before 9/2001 the "patriotic" stock portfolios performed equally well or worse than the "non-patriotic" stock portfolios, whereas they performed better after $9 / 2001$.

\section{Product market exuberance}

Another possibility as to why patriotic stock portfolios earn positive abnormal returns, is product market exuberance. That is, if during wartime, consumers prefer products of firms that have patriotic names, then our results may simply be driven by product market performance. To see if this is the case, we compare the average growth rates in sales, of patriotic and control portfolios, over the same multiple periods before and after September 2001. Sales is a less noisy and therefore better metric of product market exuberance than (say) earnings, because earnings are a function of operating expenses, which are unrelated to sentiment in the product market. Table 13 shows the differences in sales growth rates. It is clear that there is no significant difference between sales growth rates of firms with "patriotic" names and otherwise similar firms with no "patriotic" names. Thus, the former do not benefit from consumer exuberance and neither do their stock prices.

\section{Few large firms}

Our results could also be driven by a small number of large firms. If, for instance, a single large firm with a patriotic name performs well during wartime for some idiosyncratic reason, then this could drive the returns of the entire patriotic stock portfolio. To see whether this is true, we form equally weighted portfolios of patriotic stocks before and after September 2001 and estimate model (1). The results of this procedure are in Table 14. The patriotic name effect persists during wartime while it is absent before September 2001. This means that the driving force is a systematic factor (the patriotic name) and not an idiosyncratic one.

\section{IPOs}

Finally, we eliminate the possibility that the abnormal returns during the War on Terror

\footnotetext{
${ }^{18}$ The "patriotic" and match portfolios thus have almost the same average size and book-to-market.
} 
are caused by Initial Public Offering (IPO) underpricing. If during the War on Terror a higher proportion of firms going public are firms with patriotic names, then the abnormal returns that the patriotic-stock portfolios exhibit are not necessarily the result of a name bias. A simple examination of the proportion of patriotic name IPOs over total IPOs however, does not reveal any pattern during wartime ${ }^{19}$. A more formal treatment is to drop from the sample the first-month returns of all IPOs ${ }^{20}$ and estimate again model (1) over multiple periods around 9/2001. These results are shown in Table 15. The t-statistics of the intercept remain significant after September 2001 and insignificant before that date.

\section{Foreign investors}

A remark about the effects of foreign holdings is in order. Stocks with patriotic names are also held by foreign investors, especially during the WOT sample time. Nevertheless, we do not expect foreign investors to be patriotically sensitive to the outbreaks of wars that involve the US. In other words, although they may alter their positions in the US market as a response to a war outbreak, they are unlikely to treat stocks with an American patriotic name in a different manner. Thus, their behavior likely biases our results downward. Had it not been for foreign investors, the "patriotic name effect" would probably have been stronger.

\subsection{Cumulative Abnormal Returns}

We next examine how the abnormal returns, that we documented earlier, evolve over time. We do this by calculating, on a daily basis, cumulative abnormal returns (CARs) during the wartime periods that the Carhart alphas were positive and significant. Thus, we calculate CARs for WWII, Korea and the War on Terror using as starting dates June 6, 1942, June 23, 1950 and September 11, 2001 respectively.

For the War on Terror, we construct, every June, a portfolio of stocks with patriotic names and we compare the cumulative returns of this portfolio to the cumulative returns of a control portfolio. The control portfolio is constructed by matching each patriotic-name stock with a non-patriotic-name stock in the same industry (i.e. with a same four-digit SIC) and with similar size and book-to-market ratio. We then calculate the portfolios' daily returns over a time window. We do this using both equally and value-weighted daily portfolio returns. The Cumulative Abnormal Returns (CARs) are the differences of the patriotic and control portfolios' cumulative returns.

We unfortunately cannot follow the same approach for WWII and the War in Korea since book-to-market statistics are not available for the time periods covered by these two wars. Instead, we calculate CARs around the beginning of these wars using the market model. In the Appendix we describe in more detail both the match portfolio and the market model CAR calculations.

Table 16 shows the CARs of the value and equally weighted patriotic portfolios over several time windows after September 11, 2001. The CARs are positive and economically significant for all time windows and statistically significant over some of these time windows.

\footnotetext{
${ }^{19}$ We do not report these results here.

${ }^{20} \mathrm{IPO}$ abnormal returns are realized during the first few days after an IPO.
} 
Those of the equally weighted portfolios are generally more significant than those of the value-weighted portfolios. In Figure 2 we graph these CARs over time as well as the CARs over a 120 -day period preceding $9 / 11 / 2001$. The CAR of the value-weighted portfolio reaches a peak value of about $52 \%$ roughly one and a half years after 9/11/2001 and subsequently declines over the next two and a half years. That is, during years 3 and 4 there is a reversal and the value-weighted patriotic stock portfolio earns negative abnormal returns. The equally weighted portfolio exhibits no reversal during these four years probably because a mispricing on a larger firm is more easily detectable and thus more likely to be corrected sooner.

These cumulative abnormal returns are consistent with the Fama-French regression results of the zero net investment portfolio. The monthly abnormal returns (alphas) of $1.7 \%, 1 \%$, and $0.6 \%$ over 24, 36, and 48 months in Table 12 compound to a 50\%, $43 \%$ and $40 \%$ cumulative return respectively. These numbers are comparable to the value-weighted CARs for those months $(52.4 \%, 45.4 \%$ and $32 \%)$.

Regarding the WWII and Korea War time periods, we only calculate CARs for a maximum of a one year window (250 trading days) after the benchmark dates. We do this because the market model parameters - having been estimated over a time period prior to the benchmark dates - become less relevant over longer time windows by the change of the stock return distribution. Tables 17 and 18 and Figures 3 and 4 show the results of these calculations. The figures also graph the CARs over the 120-day periods preceding the benchmark dates, which are used for model parameter estimation.

Evidently, for these wars as well, the post-benchmark-date CARs are significant, both economically and statistically. For WWII, the value and equally weighted portfolios earn $29.3 \%$ and $69.2 \%$ respectively over the first year after June 6, 1942 and for the Korean War, the one-year CARs after June 26, 1950 are 24\% and 42\%. Furthermore, the Figures suggest a sharp contrast with the pre-benchmark-date CARs.

\subsubsection{Discussion of the cumulative abnormal return results}

What do the CARs tell us? First, that there is no immediate price reaction of the patriotic name stocks after the benchmark dates. Nevertheless, there is, over time, an economically significant effect. This is consistent with noise traders passively and gradually gravitating toward stocks with patriotic sounding names. The investor sentiment at play is likely not strong enough to motivate investors to actively seek and buy such stocks (in which case we would likely observe a more rapid price reaction), but it may well be causing them to buy a stock with a "patriotic name", when, in the regular process of investing, such an opportunity arises.

Second, the bias seems to be more pronounced for smaller firms as the relative performance of value- and equally weighted portfolios indicates. For WWII and the Korean War, the equally weighted portfolios outperform the value-weighted ones; for the War on Terror, the opposite is true for the first year after $9 / 11 / 2001$, but after that the value-weighted portfolio CARs start to decrease while those of the equally weighted portfolios keep increasing and are significant over longer event windows. These patterns are consistent with the idea that larger firms' stock is less likely to be mispriced, since these firms are more visible and are followed more closely by analysts. 


\section{Summary and Conclusion}

In this paper we present evidence that investors' patriotic sentiment can affect stock returns. In particular, using stock market data around and during WWII, the Korean War and the War On Terror, we show that when investors are more likely to be excited about their country, firms with "patriotic" names earn positive abnormal returns. For multi-year periods during these wars, the Carhart alpha of "patriotic" name stock portfolios is positive and significant (statistically and economically). The magnitude of the effect varies with the war that we examine: for some specifications, the monthly abnormal return is as high as $0.8 \%$ and significant at a $1 \%$ level. Furthermore, these results do not seem to be driven by industry effects, by product market exuberance, by a few large stocks or by IPOs. Over shorter horizons we find that the portfolios of stocks with patriotic names consistently earn positive abnormal returns which are also economically and statistically significant. For example, for all three wars, the value- and equally weighted portfolios earn a CAR of at least $24 \%$ (and as much as $69 \%$ ) during the first year.

To the extent that the particular war periods are associated with stronger patriotic feelings among investors, our results can be interpreted as evidence of a "patriotic name bias", whereby patriotic sentiment causes investors to slowly gravitate toward stocks with patriotic sounding names. This also implies that patriotic investor reaction is partly irrational in the sense that if investors were purchasing domestic stocks to support their country's businesses and economy, they would have no reason to concentrate on stocks with patriotic sounding names. In all these regards, we feel that this paper documents an interesting example of market inefficiency that is slowly manifested and corrected. 


\section{Appendix}

\section{Cumulative abnormal returns}

\section{A. Match Portfolios}

The day $t$ abnormal return of patriotic stock $i$ is given by

$$
A R_{i t}=R_{i t}^{p}-R_{i t}^{c}
$$

where $R_{i t}^{p}$ is the daily return of patriotic stock $i$ and $R_{i t}^{c}$ is the daily return of its match. The day $t$ abnormal return for the equally weighted portfolio is

$$
A R_{t}^{e}=\frac{\sum_{i=1}^{N_{t}} A R_{i t}}{N_{t}}
$$

where $N_{t}$ is the number of firms with patriotic names in our sample as of day $t$. The day $t$ abnormal return for the value-weighted portfolio is given by

$$
A R_{t}^{v}=\sum_{i=1}^{N} w_{i t} A R_{i t}
$$

where $w_{i t}$ is the weight that stock $i$ receives on day $t$. For both the patriotic and control portfolios we use weights calculated from the patriotic stock portfolios. That is, the weights are given by

$$
w_{i t}=\frac{P_{i t}^{p} n_{i t}}{\sum_{i=1}^{N_{t}} P_{i t}^{p} n_{i t}}
$$

where $P_{i t}^{p}$ is the price of patriotic stock $i$ on day $t$ and $n_{i t}$ is the number of its shares outstanding. Since patriotic and control stocks have been matched by size, using the same weights for both portfolios should create only a small error. The cumulative abnormal returns (CARs) over a window of $x$ days after the event is given by:

$$
C A R_{1, x}^{j}=\sum_{t=1}^{x} A R_{t}^{j}
$$

where $j=e, v$ depending whether the portfolio is equally or value-weighted.

\section{B. Market Model}

Over a period of 120 days before the benchmark date we estimate the market model:

$$
R_{t}^{j}=\alpha+\beta R_{m t}+u_{t}
$$

where $R_{t}^{j}$ is the return of the patriotic stock portfolio on day $t$ and $j=e, v$ depending whether the portfolio is equally or value weighted. We then estimate the daily patriotic portfolio abnormal returns after the benchmark date by:

$$
A R_{t}^{j}=R_{t}^{j *}-\hat{\alpha}-\hat{\beta} R_{m t}^{*}
$$


where $R_{t}^{j *}$ and $R_{m t}^{*}$ are the actual daily portfolio and market returns after the benchmark date and $\hat{\alpha}, \hat{\beta}$ are the estimated parameters of the market model. As before, the cumulative abnormal returns (CARs) over a window of $x$ days after the event is given by:

$$
C A R_{1, x}^{j}=\sum_{t=1}^{x} A R_{t}^{j}
$$

\section{Hypothesis testing}

The alternative hypotheses we want test are:

$$
\begin{aligned}
& H_{0}: C A R_{1, x}^{j}=0 \\
& H_{1}: C A R_{1, x}^{j} \neq 0
\end{aligned}
$$

The relevant statistic for this test is the ratio of the cumulative abnormal return to its estimated standard deviation:

$$
\tau=\frac{C A R_{1, x}^{j}}{\hat{S}\left(C A R_{1, x}^{j}\right)}
$$

Assuming no serial correlation of daily abnormal returns over a holdout period prior to the benchmark date and also stationarity of daily abnormal return variances after it, the test statistic can be written as

$$
\tau=\frac{C A R_{1, x}^{j}}{\sqrt{x \hat{\sigma}_{\text {holdout }, j}^{2}}}
$$

The sample variance of daily abnormal returns is calculated using data from a "holdout" period of $T$ days prior to the benchmark date. Thus, the sample variance is given by

$$
\hat{\sigma}_{\text {holdout }, j}^{2}=\frac{\sum_{t=-T}^{-1}\left(A R_{t}^{j}-\overline{A R^{j}}\right)^{2}}{T-1}
$$

where

$$
\overline{A R^{j}}=\frac{\sum_{t=-T}^{-1} A R_{t}^{j}}{T}
$$

In our case, the estimation period has a length of more than 30 days $(T>30)$ and the test statistic follows asymptotically a unit normal distribution; that is, $\tau \sim N(0,1)$. 


\section{References}

Barberis Nicholas, Shleifer Andrei and Robert Vishny, 1998, "A Model of Investor Sentiment", Journal of Financial Economics, 49, 307-343.

Bosch Jean-Claude and Mark Hirschey, 1989, "The Valuation Effects of Corporate Name Changes", Financial Management, Vol. 18, No. 4, pp 64-73

Carhart Mark, 1997, "On Persistence in Mutual Fund Performance", Journal of Finance, $52,57-82$.

Cooper Michael, Orlin Dimitrov and P. Raghavendra Rau, 2001, "A Rose.com By Any Other Name", Journal of Finance, 56, No. 6.

Fama Eugene and Kenneth French, 1993, "Common Risk Factors in the Returns on Stocks and Bonds", Journal of Financial Economics, 33, 3-56.

Fama Eugene and Kenneth French, 1995, "Size and Book-to-market Factors in Earnings and Returns", Journal of Finance, 50, 131-155.

Fama Eugene and Kenneth French, 1996, "Multifactor Explanations of Asset Pricing Anomalies", Journal of Finance, 51, 55-84.

Jegadeesh Narasimhan and Sheridan Titman, 1993, "Returns to Buying Winners and Selling Losers: Implications for Stock Market Efficiency", Journal of Finance, 48, 65-91.

Kahneman David and Amos Tversky, 1979, "Prospect Theory: An Analysis of Decision Under Risk", Econometrica, 47, 263-291.

Karpoff Jonathan and Graeme Rankine, 1994, "In Search of a Signalling Effect: The Wealth Effects of Corporate Name Changes", Journal of Banking ES Finance, 18, 1027-1045.

Kimble, James 2006. Mobilizing the home front: war bonds and domestic propaganda. Dallas: Texas A\&M University Press.

Lunch, William and Peter Sperlich, 1979, "American Public Opinion and the War in Vietnam", The Western Political Quarterly, 32(1), 21-44.

Morse Adair and Sophie Shive, 2011, "Patriotism in Your Portfolio", Journal of Financial Markets, 14 (2), 411-440.

Newey K. Whitney and Kenneth D. West, 1987, "A Simple, Positive Semi-Definite Heteroskedasticity and Autocorrelation Consistent Covariance Matrix", Econometrica, 55, No. 3, 703-708. 
Roll, Richard, 1984, "Orange Juice and Weather", American Economic Review, 74, 861880.

Roll, Richard, 1988, "R" $R^{2 ", ~ J o u r n a l ~ o f ~ F i n a n c e, ~ 43, ~ 541-566 . ~}$

Shankarmahesh, Manesh, 2006, "Consumer Ethnocentrism: An Integrative Review of its Antecedents and Consequences", International Marketing Review, 23, 146-172.

Shiller, Robert, 1981, "Do Stock Prices Move Too Much to Be Justified By Subsequent Changes in Dividends?", American Economic Review, 71, 421-436.

Sulon, Bill: "Savings Bonds Appeal to Patriotic Pennsylvania Investors", The Patriot-News, 20 November, 2001 
Table 4: Results of Fama-French regressions before and during World War II. Every month we form value-weighted portfolios of stocks with patriotic names over a period of two, three and four years before and after December 1941, after June 1942, and until the end of the war (August 1945). We then estimate the four-factor model (1) for each of the time periods. t-statistics are in parentheses. $*$, ** and $* * *$ indicate significance at $10 \%, 5 \%$ and $1 \%$, respectively.

\begin{tabular}{|c|c|c|c|c|c|}
\hline Periods & $\hat{\alpha}$ & $\hat{\beta}$ & $\hat{\gamma}$ & $\hat{\delta}$ & $\hat{\zeta}$ \\
\hline $\begin{array}{l}\text { Two years } \\
\text { before } 12 / 1941\end{array}$ & $\begin{array}{l}0.002 \\
(0.53)\end{array}$ & $\begin{array}{c}0.85 \\
(11.63)\end{array}$ & $\begin{array}{l}-0.21 \\
(-1.01)\end{array}$ & $\begin{array}{l}-0.21 \\
(-1.56)\end{array}$ & $\begin{array}{l}-0.12 \\
(-0.99)\end{array}$ \\
\hline $\begin{array}{l}\text { Three years } \\
\text { before } 12 / 1941\end{array}$ & $\begin{array}{l}0.003 \\
(1.13)\end{array}$ & $\begin{array}{c}0.83 \\
(11.54)\end{array}$ & $\begin{array}{l}-0.15 \\
(-0.86)\end{array}$ & $\begin{array}{l}-0.24 \\
(-2.77)\end{array}$ & $\begin{array}{l}-0.06 \\
(-0.92)\end{array}$ \\
\hline $\begin{array}{l}\text { Four years } \\
\text { before } 12 / 1941\end{array}$ & $\begin{array}{l}0.001 \\
(0.26)\end{array}$ & $\begin{array}{c}0.80 \\
(17.04)\end{array}$ & $\begin{array}{l}-1.12 \\
(-1.14)\end{array}$ & $\begin{array}{l}-1.14 \\
(-1.41)\end{array}$ & $\begin{array}{c}0.02 \\
(0.41)\end{array}$ \\
\hline $\begin{array}{l}\text { Two years } \\
\text { after } 12 / 1941\end{array}$ & $\begin{array}{l}-0.001 \\
(-0.18)\end{array}$ & $\begin{array}{c}0.90 \\
(6.91)\end{array}$ & $\begin{array}{c}0.12 \\
(0.69)\end{array}$ & $\begin{array}{l}-0.04 \\
(-0.24)\end{array}$ & $\begin{array}{l}-0.15 \\
(-0.93)\end{array}$ \\
\hline $\begin{array}{l}\text { Three years } \\
\text { after } 12 / 1941\end{array}$ & $\begin{array}{l}-0.001 \\
(-0.27)\end{array}$ & $\begin{array}{c}0.87 \\
(7.81)\end{array}$ & $\begin{array}{c}0.09 \\
(0.66)\end{array}$ & $\begin{array}{l}-0.02 \\
(-0.15)\end{array}$ & $\begin{array}{l}-0.12 \\
(-1.20)\end{array}$ \\
\hline End of War (August 1945) & $\begin{array}{l}0.001 \\
(0.16)\end{array}$ & $\begin{array}{c}0.79 \\
(7.90)\end{array}$ & $\begin{array}{c}0.07 \\
(0.75)\end{array}$ & $\begin{array}{c}0.01 \\
(0.12)\end{array}$ & $\begin{array}{l}-0.13 \\
(-1.44)\end{array}$ \\
\hline $\begin{array}{l}\text { Four years } \\
\text { after } 12 / 1941\end{array}$ & $\begin{array}{l}0.000 \\
(0.10)\end{array}$ & $\begin{array}{c}0.78 \\
(7.91)\end{array}$ & $\begin{array}{c}0.06 \\
(0.64)\end{array}$ & $\begin{array}{c}0.02 \\
(0.24)\end{array}$ & $\begin{array}{l}-0.13 \\
(-1.48)\end{array}$ \\
\hline
\end{tabular}


Table 5: Results of Fama-French regressions before and during the Korean War. Every month we form value-weighted portfolios of stocks with patriotic names over a period of two, three and four years before and after June 1950 and until the end of the war (July 1953). We then estimate the four-factor model (1) for each of the time periods. t-statistics are in parentheses. $*, * *$ and $* * *$ indicate significance at $10 \%, 5 \%$ and $1 \%$, respectively.

\begin{tabular}{|c|c|c|c|c|c|}
\hline Periods & $\hat{\alpha}$ & $\hat{\beta}$ & $\hat{\gamma}$ & $\hat{\delta}$ & $\hat{\zeta}$ \\
\hline $\begin{array}{l}\text { Two years } \\
\text { before } 6 / 1950\end{array}$ & $\begin{array}{l}-0.001 \\
(-0.41)\end{array}$ & $\begin{array}{c}0.61 \\
(8.08)\end{array}$ & $\begin{array}{c}0.17 \\
(1.06)\end{array}$ & $\begin{array}{l}-0.38 \\
(-2.04)\end{array}$ & $\begin{array}{l}-0.10 \\
(-0.92)\end{array}$ \\
\hline $\begin{array}{l}\text { Three years } \\
\text { before } 6 / 1950\end{array}$ & $\begin{array}{l}0.001 \\
(0.63)\end{array}$ & $\begin{array}{c}0.54 \\
(17.73)\end{array}$ & $\begin{array}{c}0.20 \\
(1.49)\end{array}$ & $\begin{array}{l}-0.16 \\
(-2.92)\end{array}$ & $\begin{array}{c}0.01 \\
(0.07)\end{array}$ \\
\hline $\begin{array}{l}\text { Four years } \\
\text { before } 6 / 1950\end{array}$ & $\begin{array}{l}-0.001 \\
(-0.73)\end{array}$ & $\begin{array}{c}0.57 \\
(9.82)\end{array}$ & $\begin{array}{c}0.29 \\
(2.22)\end{array}$ & $\begin{array}{l}-0.19 \\
(-2.51)\end{array}$ & $\begin{array}{c}0.08 \\
(1.00)\end{array}$ \\
\hline $\begin{array}{l}\text { Two years } \\
\text { after } 6 / 1950\end{array}$ & $\begin{array}{l}0.001 \\
(0.94)\end{array}$ & $\begin{array}{c}0.52 \\
(5.94)\end{array}$ & $\begin{array}{c}0.07 \\
(0.78)\end{array}$ & $\begin{array}{l}-0.11 \\
(-3.57)\end{array}$ & $\begin{array}{c}0.01 \\
(0.11)\end{array}$ \\
\hline $\begin{array}{l}\text { Three years } \\
\text { after } 6 / 1950\end{array}$ & $\begin{array}{l}0.002 \\
(1.51)\end{array}$ & $\begin{array}{c}0.57 \\
(8.66)\end{array}$ & $\begin{array}{c}0.07 \\
(1.06)\end{array}$ & $\begin{array}{l}-0.10 \\
(-3.26)\end{array}$ & $\begin{array}{l}-0.04 \\
(-0.64)\end{array}$ \\
\hline End of War (July 1953) & $\begin{array}{l}0.002 \\
(1.66)\end{array}$ & $\begin{array}{c}0.57 \\
(9.02)\end{array}$ & $\begin{array}{c}0.07 \\
(1.01)\end{array}$ & $\begin{array}{l}-0.10 \\
(-3.28)\end{array}$ & $\begin{array}{l}-0.05 \\
(-0.72)\end{array}$ \\
\hline $\begin{array}{l}\text { Four years } \\
\text { after } 6 / 1950\end{array}$ & $\begin{array}{c}0.002 \\
(2.05)^{* *}\end{array}$ & $\begin{array}{c}0.55 \\
(12.69)\end{array}$ & $\begin{array}{c}0.06 \\
(0.95)\end{array}$ & $\begin{array}{l}-0.11 \\
(-3.74)\end{array}$ & $\begin{array}{l}-0.00 \\
(-0.16)\end{array}$ \\
\hline
\end{tabular}


Table 6: Results of Fama-French regressions before and after August 1964, the month when the US Congress authorized military action in Vietnam. Every month we form value-weighted portfolios of stocks with patriotic names over a period of two, three and four years before and after this date. We then estimate the four-factor model (1) for each of the time periods. t-statistics are in parentheses. $*$, ** and $* * *$ indicate significance at $10 \%, 5 \%$ and $1 \%$, respectively.

\begin{tabular}{|c|c|c|c|c|c|}
\hline Periods & $\hat{\alpha}$ & $\hat{\beta}$ & $\hat{\gamma}$ & $\hat{\delta}$ & $\hat{\zeta}$ \\
\hline $\begin{array}{l}\text { Two years } \\
\text { before } 08 / 1964\end{array}$ & $\begin{array}{l}0.004 \\
(0.58)\end{array}$ & $\begin{array}{c}0.69 \\
(5.15)\end{array}$ & $\begin{array}{l}-0.26 \\
(-1.49)\end{array}$ & $\begin{array}{l}-0.24 \\
(-0.96)\end{array}$ & $\begin{array}{l}-0.17 \\
(-0.86)\end{array}$ \\
\hline $\begin{array}{l}\text { Three years } \\
\text { before } 08 / 1964\end{array}$ & $\begin{array}{l}0.004 \\
(0.94)\end{array}$ & $\begin{array}{c}0.82 \\
(13.83)\end{array}$ & $\begin{array}{l}-0.11 \\
(-0.63)\end{array}$ & $\begin{array}{l}-0.44 \\
(-3.04)\end{array}$ & $\begin{array}{l}-0.11 \\
(-0.87)\end{array}$ \\
\hline $\begin{array}{l}\text { Four years } \\
\text { before } 08 / 1964\end{array}$ & $\begin{array}{l}0.004 \\
(1.03)\end{array}$ & $\begin{array}{c}0.96 \\
(11.33)\end{array}$ & $\begin{array}{l}-0.18 \\
(-1.11)\end{array}$ & $\begin{array}{l}-0.32 \\
(-2.25)\end{array}$ & $\begin{array}{c}0.03 \\
(0.22)\end{array}$ \\
\hline $\begin{array}{l}\text { Two years } \\
\text { after } 08 / 1964\end{array}$ & $\begin{array}{l}-0.008 \\
(-2.22)\end{array}$ & $\begin{array}{c}0.66 \\
(4.44)\end{array}$ & $\begin{array}{l}-0.10 \\
(-0.48)\end{array}$ & $\begin{array}{l}-0.30 \\
(-1.20)\end{array}$ & $\begin{array}{c}0.02 \\
(0.14)\end{array}$ \\
\hline $\begin{array}{l}\text { Three years } \\
\text { after } 08 / 1964\end{array}$ & $\begin{array}{l}-0.004 \\
(-0.96)\end{array}$ & $\begin{array}{c}0.82 \\
(5.25)\end{array}$ & $\begin{array}{l}-0.26 \\
(-1.07)\end{array}$ & $\begin{array}{l}-0.04 \\
(-0.18)\end{array}$ & $\begin{array}{l}-0.07 \\
(-0.42)\end{array}$ \\
\hline $\begin{array}{l}\text { Four years } \\
\text { after } 08 / 1964\end{array}$ & $\begin{array}{l}-0.003 \\
(-0.81)\end{array}$ & $\begin{array}{c}0.71 \\
(4.45)\end{array}$ & $\begin{array}{l}-0.10 \\
(-0.49)\end{array}$ & $\begin{array}{c}0.06 \\
(0.38)\end{array}$ & $\begin{array}{l}-0.19 \\
(-1.58)\end{array}$ \\
\hline
\end{tabular}


Table 7: Results of Fama-French regressions before and during the War On Terror. Every month we form value-weighted portfolios of stocks with patriotic names over a period of two, three and four years before and after September 2001. We then estimate the four-factor model (1) for each of the time periods. t-statistics are in parentheses. $*, * *$ and $* * *$ indicate significance at $10 \%, 5 \%$ and $1 \%$, respectively.

\begin{tabular}{|c|c|c|c|c|c|}
\hline Periods & $\hat{\alpha}$ & $\hat{\beta}$ & $\hat{\gamma}$ & $\hat{\delta}$ & $\hat{\zeta}$ \\
\hline $\begin{array}{l}\text { Two years } \\
\text { before } 9 / 2001\end{array}$ & $\begin{array}{l}0.007 \\
(0.67)\end{array}$ & $\begin{array}{c}0.76 \\
(3.76)\end{array}$ & $\begin{array}{l}-0.64 \\
(-2.26)\end{array}$ & $\begin{array}{l}-0.04 \\
(-0.13)\end{array}$ & $\begin{array}{c}0.16 \\
(1.54)\end{array}$ \\
\hline $\begin{array}{l}\text { Three years } \\
\text { before } 9 / 2001\end{array}$ & $\begin{array}{l}0.005 \\
(0.61)\end{array}$ & $\begin{array}{c}0.85 \\
(5.28)\end{array}$ & $\begin{array}{l}-0.69 \\
(-3.64)\end{array}$ & $\begin{array}{l}-0.05 \\
(-0.23)\end{array}$ & $\begin{array}{c}0.19 \\
(2.15)\end{array}$ \\
\hline $\begin{array}{l}\text { Four years } \\
\text { before } 9 / 2001\end{array}$ & $\begin{array}{l}0.001 \\
(0.23)\end{array}$ & $\begin{array}{c}1.02 \\
(7.99)\end{array}$ & $\begin{array}{l}-0.56 \\
(-3.56)\end{array}$ & $\begin{array}{c}0.11 \\
(0.57)\end{array}$ & $\begin{array}{c}0.18 \\
(2.15)\end{array}$ \\
\hline $\begin{array}{l}\text { Two years } \\
\text { after } 9 / 2001\end{array}$ & $\begin{array}{c}0.010 \\
(2.73)^{* * *}\end{array}$ & $\begin{array}{c}1.16 \\
(8.92)\end{array}$ & $\begin{array}{l}-0.03 \\
(-0.18)\end{array}$ & $\begin{array}{c}0.26 \\
(1.45)\end{array}$ & $\begin{array}{c}0.26 \\
(2.17)\end{array}$ \\
\hline $\begin{array}{l}\text { Three years } \\
\text { after } 9 / 2001\end{array}$ & $\begin{array}{c}0.008 \\
(2.61)^{* *}\end{array}$ & $\begin{array}{c}0.88 \\
(4.64)\end{array}$ & $\begin{array}{l}-0.10 \\
(-0.60)\end{array}$ & $\begin{array}{c}0.32 \\
(1.87)\end{array}$ & $\begin{array}{c}0.03 \\
(0.24)\end{array}$ \\
\hline $\begin{array}{l}\text { Four years } \\
\text { after } 9 / 2001\end{array}$ & $\begin{array}{c}0.006 \\
(2.13)^{* *}\end{array}$ & $\begin{array}{c}0.79 \\
(5.26)\end{array}$ & $\begin{array}{l}-0.11 \\
(-0.68)\end{array}$ & $\begin{array}{c}0.30 \\
(1.72)\end{array}$ & $\begin{array}{l}-0.05 \\
(-0.49)\end{array}$ \\
\hline
\end{tabular}


Table 8: Estimated intercepts (alphas) and t-statistics from Fama-French regressions during multiple four-year periods during the Vietnam War. Every month we form value-weighted portfolios of stocks with patriotic names and estimate the four-factor model (1) for each of the four-year time periods. Because the exact date of the beginning of the Vietnam war is disputed or unclear, we provide for the purpose of comparison several key dates along with a short description of the events that occurred on these dates (Source: Wikipedia).

\begin{tabular}{cccccc}
\hline \hline $\begin{array}{c}\text { Time } \\
\text { Period }\end{array}$ & $\begin{array}{c}\text { Jensen's } \\
\text { alpha }\end{array}$ & t-statistic & $\begin{array}{c}\text { Time } \\
\text { Period }\end{array}$ & $\begin{array}{c}\text { Jensen's } \\
\text { alpha }\end{array}$ & t-statistic \\
\hline 1950-53 & 0.001 & 0.81 & $1963-66$ & -0.001 & -0.44 \\
$1951-54$ & 0.001 & 1.52 & $1964-67$ & -0.004 & -1.09 \\
$1952-55$ & 0.001 & 0.62 & $1965-68$ & -0.001 & -0.24 \\
$1953-56$ & 0.001 & 0.63 & $1966-69$ & 0.001 & 0.31 \\
$1954-57$ & 0.001 & 0.38 & $1967-70$ & -0.001 & -0.44 \\
$1955-58$ & 0.005 & 1.55 & $1968-71$ & -0.001 & -0.27 \\
$1956-59$ & 0.005 & 1.41 & $1969-72$ & -0.001 & -0.23 \\
$1957-60$ & 0.008 & 2.11 & $1970-73$ & -0.002 & -0.82 \\
$1958-61$ & 0.008 & 1.80 & $1971-74$ & 0.002 & 0.69 \\
$1959-62$ & 0.006 & 1.30 & $1972-75$ & 0.002 & 0.71 \\
$1960-63$ & 0.008 & 1.66 & $1973-76$ & 0.003 & 1.00 \\
$1961-64$ & 0.001 & 0.27 & $1974-77$ & 0.004 & 1.43 \\
$1962-65$ & 0.000 & -0.05 & $1975-78$ & 0.002 & 0.71 \\
\hline
\end{tabular}

Date

Event

09/27/1950 The US establishes the Military Assistance Advisory Group (MAAG) Indochina in Saigon, to aid the French military.

11/01/1955 The US redesignates MAAG Indochina, as MAAG Vietnam to specify its new direct combat advisory role with the South Vietnamese Army. The Department of Defense views this date as the earliest qualifying date for inclusion on the Vietnam Veterans Memorial.

03/1959 Ho Chi Minh declares a people's war to unite all of Vietnam under his leadership. His Politburo orders a changeover to an all-out military struggle. From the communist perspective, the "Vietnam War" against the US has now officially started.

12/11/1961 The aircraft carrier USS Core arrives in Saigon with 33 helicopters and 400 air and ground crewmen assigned to operate them for the South Vietnamese Army. Also, US pilots start to train and fly support missions with the South Vietnamese Air Force. This marks the first larger scale participation of US "advisors".

08/07/1964 In response to the incidents involving the US naval vessels USS Maddox and USS Turner Joy, the US Congress overwhelmingly passes the "Gulf of Tonkin Resolution" allowing the President "to take all necessary steps, including the use of armed force" to prevent further attacks against US forces.

03/08/1965 The first US combat troops arrive in Vietnam as 3.500 marines land at China Beach to defend the American air base at Da Nang. They join 23,000 military advisors already in Vietnam. The arrival of combat troops is considered by some the start of the war although American military advisors have been in Vietnam for over 10 years. 
Table 9: Results of Fama-French regressions during World War II, excluding the first six months of the war. Starting in June 1942 (month of Midway battle), we form every month value-weighted portfolios of stocks with patriotic names over periods of two, three and four years and until the end of the war (August 1945). We then estimate the four-factor model (1) for each of the time periods. t-statistics are in parentheses. $*, * *$ and $* * *$ indicate significance at $10 \%, 5 \%$ and $1 \%$, respectively.

\begin{tabular}{l|ccccc}
\hline \hline \multirow{2}{*}{ Periods } & $\hat{\alpha}$ & $\hat{\beta}$ & $\hat{\gamma}$ & $\hat{\delta}$ & $\hat{\zeta}$ \\
\hline $\begin{array}{l}\text { Two years } \\
\text { after 6/1942 }\end{array}$ & $\mathbf{0 . 0 0 6}$ & 0.50 & 0.21 & 0.16 & -0.10 \\
\hline & $\mathbf{( 2 . 3 1 ) ^ { * * }}$ & $(4.18)$ & $(1.54)$ & $(0.99)$ & $(-0.84)$ \\
\hline $\begin{array}{l}\text { Three years } \\
\text { after 6/1942 }\end{array}$ & $\mathbf{0 . 0 0 4}$ & 0.53 & 0.17 & 0.14 & -0.09 \\
\hline \multirow{2}{*}{$\begin{array}{l}\text { End of War (August 1945) } \\
\text { (1.85)* }\end{array}$} & $\mathbf{0 . 0 0 5}$ & 0.52 & 0.20 & 0.10 & -0.09 \\
& $\mathbf{( 2 . 3 0 ) * *}$ & $(7.40)$ & $(2.01)$ & $(1.18)$ & $(-1.14)$ \\
\hline \multirow{2}{*}{$\begin{array}{l}\text { Four years } \\
\text { after 6/1942 }\end{array}$} & $\mathbf{0 . 0 0 5}$ & 0.53 & 0.16 & 0.12 & -0.10 \\
\hline
\end{tabular}

Table 10: Results of Fama-French regressions during combined four-year periods before and during WWII, the War in Korea and the War on Terror. Every month of these periods, we form value-weighted portfolios of stocks with patriotic names. We then estimate the four-factor model (1). For WWII we exclude the six-month period between the attack on Pearl Harbor and the Midway battle. t-statistics are in parentheses. *, $* *$ and $* * *$ indicate significance at $10 \%, 5 \%$ and $1 \%$, respectively.

\begin{tabular}{l|cccccc}
\hline \hline Periods & $\hat{\alpha}$ & $\hat{\beta}$ & $\hat{\gamma}$ & $\hat{\delta}$ & $\hat{\zeta}$ \\
\hline $\begin{array}{l}\text { Four years before } \\
\text { beginning of wars }\end{array}$ & $\mathbf{0 . 0 0 0}$ & 0.85 & -0.41 & 0.03 & 0.10 \\
\hline \hline & $\mathbf{( 0 . 0 6 )}$ & $(15.44)$ & $(-5.74)$ & $(0.37)$ & $(1.06)$ \\
\hline $\begin{array}{l}\text { Four years after beginning of wars, } \\
12 / 1941-6 / 1942 \text { period excluded }\end{array}$ & $\mathbf{0 . 0 0 5}$ & 0.62 & -0.04 & 0.11 & -0.12 \\
\hline
\end{tabular}


Table 11: Results of Fama-French regressions of a control sample during and before the War On Terror. Every month, we construct a match sample for the stocks with a patriotic name. The match sample consists of stocks that do not have a patriotic name, but are in the same industry and have similar size and book to market. The returns of these ("non-patriotic" name) stocks are then used to estimate model (1). t-statistics are in parentheses. $*, * *$ and $* * *$ indicate significance at $10 \%, 5 \%$ and $1 \%$, respectively.

\begin{tabular}{|c|c|c|c|c|c|}
\hline Periods & $\hat{\alpha}$ & $\hat{\beta}$ & $\hat{\gamma}$ & $\hat{\delta}$ & $\hat{\zeta}$ \\
\hline $\begin{array}{l}\text { Two years } \\
\text { before } 9 / 2001\end{array}$ & $\begin{array}{l}0.007 \\
(0.81)\end{array}$ & $\begin{array}{c}0.33 \\
(1.02)\end{array}$ & $\begin{array}{l}-0.41 \\
(-1.77)\end{array}$ & $\begin{array}{l}-0.18 \\
(-0.45)\end{array}$ & $\begin{array}{c}0.29 \\
(2.93)\end{array}$ \\
\hline $\begin{array}{l}\text { Three years } \\
\text { before } 9 / 2001\end{array}$ & $\begin{array}{l}0.005 \\
(0.74)\end{array}$ & $\begin{array}{c}0.64 \\
(2.97)\end{array}$ & $\begin{array}{l}-0.16 \\
(-1.02)\end{array}$ & $\begin{array}{c}0.18 \\
(0.68)\end{array}$ & $\begin{array}{c}0.22 \\
(2.65)\end{array}$ \\
\hline $\begin{array}{l}\text { Four years } \\
\text { before } 9 / 2001\end{array}$ & $\begin{array}{l}0.001 \\
(0.26)\end{array}$ & $\begin{array}{c}0.79 \\
(5.73)\end{array}$ & $\begin{array}{l}-0.04 \\
(-0.30)\end{array}$ & $\begin{array}{c}0.32 \\
(1.47)\end{array}$ & $\begin{array}{c}0.20 \\
(2.41)\end{array}$ \\
\hline $\begin{array}{l}\text { Two years } \\
\text { after } 9 / 2001\end{array}$ & $\begin{array}{l}-0.006 \\
(-0.87)\end{array}$ & $\begin{array}{c}0.89 \\
(5.13)\end{array}$ & $\begin{array}{c}0.18 \\
(0.78)\end{array}$ & $\begin{array}{c}0.33 \\
(1.47)\end{array}$ & $\begin{array}{c}0.29 \\
(1.65)\end{array}$ \\
\hline $\begin{array}{l}\text { Three years } \\
\text { after } 9 / 2001\end{array}$ & $\begin{array}{l}-0.001 \\
(-0.25)\end{array}$ & $\begin{array}{c}0.93 \\
(7.58)\end{array}$ & $\begin{array}{c}0.19 \\
(1.00)\end{array}$ & $\begin{array}{c}0.30 \\
(1.67)\end{array}$ & $\begin{array}{c}0.32 \\
(3.06)\end{array}$ \\
\hline $\begin{array}{l}\text { Four years } \\
\text { after } 9 / 2001\end{array}$ & $\begin{array}{l}-0.001 \\
(-0.22)\end{array}$ & $\begin{array}{c}0.88 \\
(7.45)\end{array}$ & $\begin{array}{c}0.16 \\
(0.91)\end{array}$ & $\begin{array}{c}0.28 \\
(1.62)\end{array}$ & $\begin{array}{c}0.28 \\
(2.60)\end{array}$ \\
\hline
\end{tabular}


Table 12: Performance of a portfolio that is long in stocks with patriotic names and short in match stocks with no patriotic names, before and during the War on Terror. Every month, we construct a value-weighted portfolio of stocks with patriotic names along with a match portfolio containing stocks that don't have patriotic names, but are in the same industry and have similar size and book to market as the patriotic name stocks. We go long the patriotic stock portfolios and short their matches. The difference in returns is regressed on the the four risk factors of model (1). We regress the return differences over two, three and four-year periods before and after September 2001. t-statistics are in parentheses. $*, * *$ and $* * *$ indicate significance at $10 \%, 5 \%$ and $1 \%$, respectively.

\begin{tabular}{|c|c|c|c|c|c|}
\hline Periods & $\hat{\alpha}$ & $\hat{\beta}$ & $\hat{\gamma}$ & $\hat{\delta}$ & $\hat{\zeta}$ \\
\hline $\begin{array}{l}\text { Two years } \\
\text { before } 9 / 2001\end{array}$ & $\begin{array}{l}-0.003 \\
(-0.21)\end{array}$ & $\begin{array}{c}0.40 \\
(0.92)\end{array}$ & $\begin{array}{c}-0.26 \\
(-0.75)\end{array}$ & $\begin{array}{c}0.08 \\
(0.14)\end{array}$ & $\begin{array}{l}-0.13 \\
(-1.02)\end{array}$ \\
\hline $\begin{array}{l}\text { Three years } \\
\text { before } 9 / 2001\end{array}$ & $\begin{array}{l}-0.014 \\
(-1.35)\end{array}$ & $\begin{array}{c}0.15 \\
(0.53)\end{array}$ & $\begin{array}{l}-0.30 \\
(-1.41)\end{array}$ & $\begin{array}{c}-0.01 \\
(-0.02)\end{array}$ & $\begin{array}{l}-0.08 \\
(-0.66)\end{array}$ \\
\hline $\begin{array}{l}\text { Four years } \\
\text { before } 9 / 2001\end{array}$ & $\begin{array}{l}-0.009 \\
(-1.12)\end{array}$ & $\begin{array}{c}0.01 \\
(0.08)\end{array}$ & $\begin{array}{l}-0.40 \\
(-2.35)\end{array}$ & $\begin{array}{l}-0.15 \\
(-0.51)\end{array}$ & $\begin{array}{l}-0.06 \\
(-0.53)\end{array}$ \\
\hline $\begin{array}{l}\text { Two years } \\
\text { after } 9 / 2001\end{array}$ & $\begin{array}{c}0.017 \\
(2.35)^{* *}\end{array}$ & $\begin{array}{c}0.26 \\
(1.21)\end{array}$ & $\begin{array}{l}-0.25 \\
(-1.16)\end{array}$ & $\begin{array}{c}-0.07 \\
(-0.24)\end{array}$ & $\begin{array}{l}-0.03 \\
(-0.13)\end{array}$ \\
\hline $\begin{array}{l}\text { Three years } \\
\text { after } 9 / 2001\end{array}$ & $\begin{array}{l}0.010 \\
(1.58)\end{array}$ & $\begin{array}{l}-0.08 \\
(-0.40)\end{array}$ & $\begin{array}{l}-0.32 \\
(-1.59)\end{array}$ & $\begin{array}{c}0.01 \\
(0.05)\end{array}$ & $\begin{array}{l}-0.30 \\
(-1.78)\end{array}$ \\
\hline $\begin{array}{l}\text { Four years } \\
\text { after } 9 / 2001\end{array}$ & $\begin{array}{l}0.006 \\
(1.42)\end{array}$ & $\begin{array}{l}-0.12 \\
(-0.80)\end{array}$ & $\begin{array}{l}-0.31 \\
(-1.65)\end{array}$ & $\begin{array}{c}0.00 \\
(0.02)\end{array}$ & $\begin{array}{l}-0.33 \\
(-2.61)\end{array}$ \\
\hline
\end{tabular}


Table 13: Every year we construct a portfolio of stocks with patriotic names over a two, three and four year period before and after September 2001. We also construct a control portfolio containing stocks that don't have patriotic names, but are in the same industry and have similar size and book to market as the patriotic name stocks. We then average the differences of sales growth rates between patriotic and control stocks every quarter of the multi-year periods. t-statistics of the pairwise mean comparison are in parentheses. $*, * *$ and $* * *$ indicate significance at $10 \%, 5 \%$ and $1 \%$, respectively.

\begin{tabular}{cccc}
\hline \hline Periods & Mean difference & Periods & Mean difference \\
\hline $\begin{array}{c}\text { Two years } \\
\text { before } 9 / 2001\end{array}$ & 0.030 & Two years & -0.001 \\
& $(0.710)$ & after $9 / 2001$ & $(-0.055)$ \\
Three years & 0.012 & Three years & -0.001 \\
before $9 / 2001$ & $(0.408)$ & after $9 / 2001$ & $(-0.082)$ \\
\hline Four years & & & \\
before $9 / 2001$ & $(0.486)$ & after $9 / 2001$ & $(-0.222)$ \\
\hline
\end{tabular}


Table 14: Results of Fama-French regressions during and before the War On Terror. Every month we form equally weighted portfolios of stocks with patriotic names over a period of two, three and four years before and after September 2001. We then estimate the four-factor model (1) for each of the time periods. t-statistics are in parentheses. $*, * *$ and $* * *$ indicate significance at $10 \%, 5 \%$ and $1 \%$, respectively.

\begin{tabular}{|c|c|c|c|c|c|}
\hline Periods & $\hat{\alpha}$ & $\hat{\beta}$ & $\hat{\gamma}$ & $\hat{\delta}$ & $\hat{\zeta}$ \\
\hline $\begin{array}{l}\text { Two years } \\
\text { before } 9 / 2001\end{array}$ & $\begin{array}{l}0.004 \\
(0.41)\end{array}$ & $\begin{array}{c}0.87 \\
(2.88)\end{array}$ & $\begin{array}{c}0.96 \\
(3.79)\end{array}$ & $\begin{array}{c}0.54 \\
(1.70)\end{array}$ & $\begin{array}{l}-0.47 \\
(-2.61)\end{array}$ \\
\hline $\begin{array}{l}\text { Three years } \\
\text { before } 9 / 2001\end{array}$ & $\begin{array}{l}0.003 \\
(0.41)\end{array}$ & $\begin{array}{c}0.77 \\
(3.68)\end{array}$ & $\begin{array}{c}0.88 \\
(5.13)\end{array}$ & $\begin{array}{c}0.43 \\
(1.90)\end{array}$ & $\begin{array}{l}-0.43 \\
(-2.58)\end{array}$ \\
\hline $\begin{array}{l}\text { Four years } \\
\text { before } 9 / 2001\end{array}$ & $\begin{array}{l}0.004 \\
(0.53)\end{array}$ & $\begin{array}{c}0.86 \\
(6.53)\end{array}$ & $\begin{array}{c}0.90 \\
(6.12)\end{array}$ & $\begin{array}{c}0.47 \\
(2.57)\end{array}$ & $\begin{array}{l}-0.42 \\
(-2.63)\end{array}$ \\
\hline $\begin{array}{l}\text { Two years } \\
\text { after } 9 / 2001\end{array}$ & $\begin{array}{c}0.008 \\
(2.05) * *\end{array}$ & $\begin{array}{c}0.79 \\
(4.76)\end{array}$ & $\begin{array}{c}0.71 \\
(3.63)\end{array}$ & $\begin{array}{c}0.60 \\
(3.83)\end{array}$ & $\begin{array}{l}-0.07 \\
(-0.65)\end{array}$ \\
\hline $\begin{array}{l}\text { Three years } \\
\text { after } 9 / 2001\end{array}$ & $\begin{array}{c}0.008 \\
(2.63)^{* *}\end{array}$ & $\begin{array}{c}0.77 \\
(5.41)\end{array}$ & $\begin{array}{c}0.75 \\
(4.45)\end{array}$ & $\begin{array}{c}0.55 \\
(3.66)\end{array}$ & $\begin{array}{l}-0.07 \\
(-0.90)\end{array}$ \\
\hline $\begin{array}{l}\text { Four years } \\
\text { after } 9 / 2001\end{array}$ & $\begin{array}{c}0.008 \\
(3.02)^{* * *}\end{array}$ & $\begin{array}{c}0.82 \\
(5.75)\end{array}$ & $\begin{array}{c}0.76 \\
(4.89)\end{array}$ & $\begin{array}{c}0.54 \\
(4.09)\end{array}$ & $\begin{array}{l}-0.04 \\
(-0.49)\end{array}$ \\
\hline
\end{tabular}


Table 15: Every month over two, three and four-year periods, before and after September 2001 we form value-weighted portfolios of stocks with patriotic names. We then drop the first month returns of all IPOs. We use the resulting sample to estimate model (1). t-statistics are in parentheses. $*, * *$ and $* * *$ indicate significance at $10 \%$, $5 \%$ and $1 \%$, respectively.

\begin{tabular}{|c|c|c|c|c|c|}
\hline Periods & $\hat{\alpha}$ & $\hat{\beta}$ & $\hat{\gamma}$ & $\hat{\delta}$ & $\hat{\zeta}$ \\
\hline $\begin{array}{l}\text { Two years } \\
\text { before } 9 / 2001\end{array}$ & $\begin{array}{l}0.007 \\
(0.66)\end{array}$ & $\begin{array}{l}0.76 \\
(3.75)\end{array}$ & $\begin{array}{l}-0.64 \\
(-2.26)\end{array}$ & $\begin{array}{l}-0.04 \\
(-0.13)\end{array}$ & $\begin{array}{c}0.16 \\
(1.53)\end{array}$ \\
\hline $\begin{array}{l}\text { Three years } \\
\text { before } 9 / 2001\end{array}$ & $\begin{array}{l}0.005 \\
(0.59)\end{array}$ & $\begin{array}{c}0.85 \\
(5.28)\end{array}$ & $\begin{array}{l}-0.69 \\
(-3.64)\end{array}$ & $\begin{array}{l}-0.05 \\
(-0.23)\end{array}$ & $\begin{array}{c}0.19 \\
(2.14)\end{array}$ \\
\hline $\begin{array}{l}\text { Four years } \\
\text { before } 9 / 2001\end{array}$ & $\begin{array}{l}0.001 \\
(0.22)\end{array}$ & $\begin{array}{l}1.02 \\
(8.05)\end{array}$ & $\begin{array}{l}-0.56 \\
(-3.57)\end{array}$ & $\begin{array}{c}0.11 \\
(0.56)\end{array}$ & $\begin{array}{c}0.18 \\
(2.15)\end{array}$ \\
\hline $\begin{array}{l}\text { Two years } \\
\text { after } 9 / 2001\end{array}$ & $\begin{array}{c}0.010 \\
(2.73)^{* * *}\end{array}$ & $\begin{array}{l}1.16 \\
(9.00)\end{array}$ & $\begin{array}{l}-0.03 \\
(-0.17)\end{array}$ & $\begin{array}{c}0.26 \\
(1.44)\end{array}$ & $\begin{array}{c}0.26 \\
(2.19)\end{array}$ \\
\hline $\begin{array}{l}\text { Three years } \\
\text { after } 9 / 2001\end{array}$ & $\begin{array}{c}0.008 \\
(2.61)^{* *}\end{array}$ & $\begin{array}{c}0.88 \\
(4.65)\end{array}$ & $\begin{array}{l}-0.10 \\
(-0.60)\end{array}$ & $\begin{array}{c}0.32 \\
(1.86)\end{array}$ & $\begin{array}{c}0.03 \\
(0.24)\end{array}$ \\
\hline $\begin{array}{l}\text { Four years } \\
\text { after } 9 / 2001\end{array}$ & $\begin{array}{c}0.006 \\
(2.16)^{* *}\end{array}$ & $\begin{array}{c}0.79 \\
(5.30)\end{array}$ & $\begin{array}{l}-0.11 \\
(-0.68)\end{array}$ & $\begin{array}{c}0.30 \\
(1.71)\end{array}$ & $\begin{array}{l}-0.04 \\
(-0.46)\end{array}$ \\
\hline
\end{tabular}


Table 16: Cumulative abnormal returns (CARs) of value and equally weighted portfolios, consisting of stocks with patriotic names over different time windows after September 11, $2001(t=0)$. The CARs are calculated over control portfolios that have been constructed by matching each patriotic stock with one that does not have a patriotic name but is in the same industry and has similar size and book to market. The patriotic and control portfolios are constructed every June, starting with June 2001. t-statistics are in parentheses; t-statistics that are significant at ten percent are bold. $*, * *$ and $* * *$ indicate significance at $10 \%, 5 \%$ and $1 \%$, respectively.

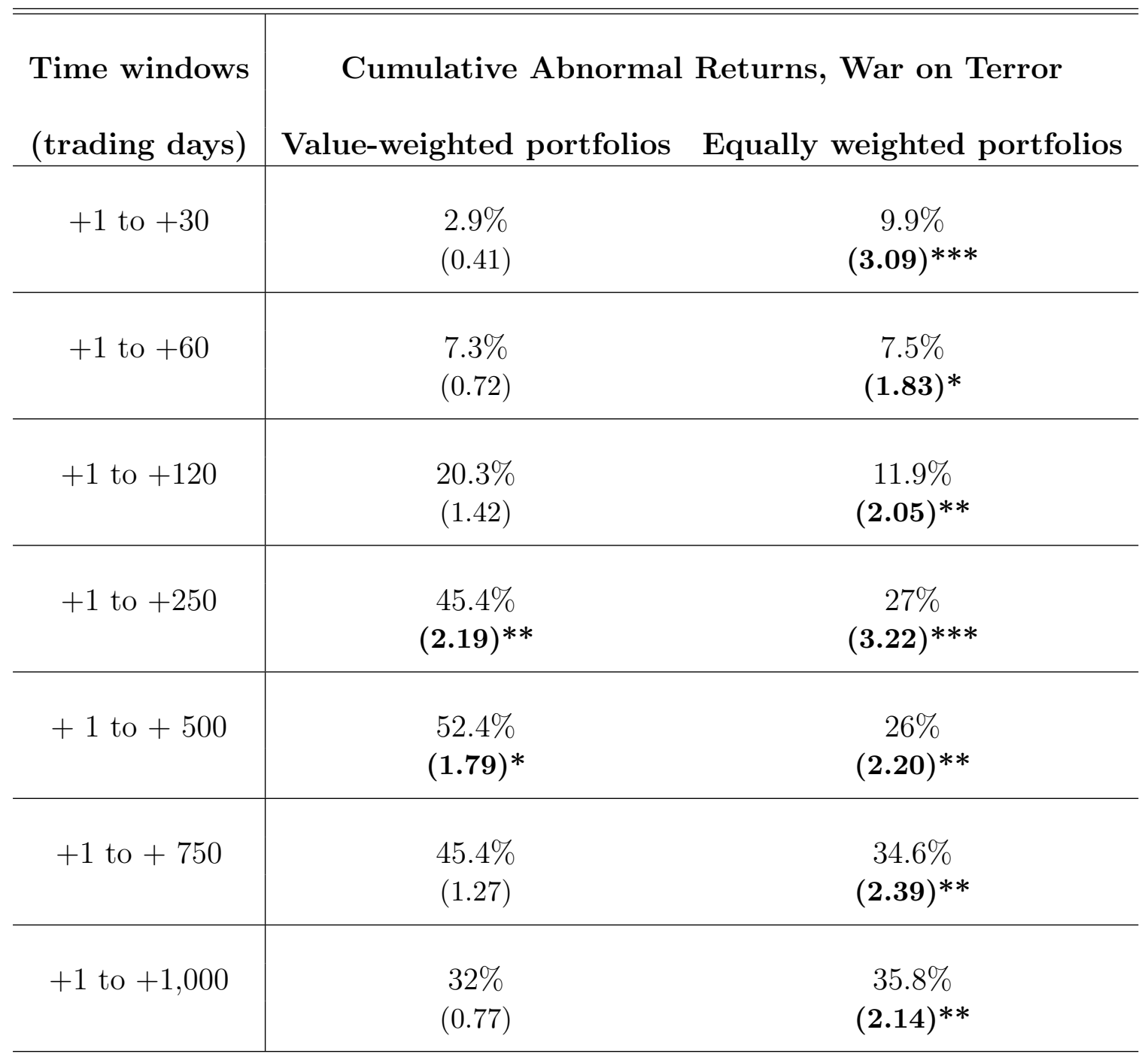


Table 17: Cumulative abnormal returns (CARs) of value and equally weighted portfolios, consisting of stocks with patriotic names over different time windows after June 6, $1942(t=0)$. The portfolios remain fixed for the duration of all time periods. The CARs are calculated using the market model as benchmark. t-statistics are in parentheses; t-statistics that are significant at ten percent are bold. *, ** and *** indicate significance at $10 \%, 5 \%$ and $1 \%$, respectively.

\begin{tabular}{c|cc}
\hline \hline \multirow{2}{*}{ Time windows } & \multicolumn{2}{|c}{ Cumulative Abnormal Returns, WWII } \\
(trading days) & Value-weighted portfolios & Equally weighted portfolios \\
\hline \multirow{2}{*}{+1 to +30} & $-1.8 \%$ & $3.9 \%$ \\
& $(-0.39)$ & $(0.86)$ \\
\hline+1 to +60 & $-1 \%$ & $4.2 \%$ \\
& $(-0.16)$ & $(0.65)$ \\
\hline+1 to +120 & $6.6 \%$ & $22.7 \%$ \\
& $(0.73)$ & $\mathbf{( 2 . 4 7})^{* *}$ \\
& & $69.2 \%$ \\
+1 to +250 & $29.3 \%$ & $\mathbf{( 5 . 2 4})^{* * *}$ \\
\hline
\end{tabular}


Table 18: Cumulative abnormal returns (CARs) of value and equally weighted portfolios, consisting of stocks with patriotic names over different time windows after June 23, $1950(t=0)$. The portfolios remain fixed for the duration of all time periods. The CARs are calculated using the market model as benchmark. t-statistics are in parentheses; t-statistics that are significant at ten percent are bold. *, ** and *** indicate significance at $10 \%, 5 \%$ and $1 \%$, respectively.

\begin{tabular}{c|cc}
\hline \hline \multirow{2}{*}{ Time windows } & Cumulative Abnormal Returns, War in Korea \\
(trading days) & Value-weighted portfolios & Equally weighted portfolios \\
\hline+1 to +30 & $-4 \%$ & $1.1 \%$ \\
& $(-2.48)^{* *}$ & $(0.4)$ \\
\hline+1 to +60 & $0.9 \%$ & $8.8 \%$ \\
& $(0.43)$ & $(\mathbf{2 . 2 7})^{* *}$ \\
\hline+1 to +120 & $5.6 \%$ & $16.6 \%$ \\
& $(1.71)$ & $\mathbf{( 3 . 0 3})^{* * *}$ \\
\hline & & $41.7 \%$ \\
& $23.9 \%$ & $(\mathbf{5 . 2 7})^{* * *}$ \\
\hline
\end{tabular}


Figure 1: Actual and predicted number of English language news articles in the Nexis database containing the phrases "American patriotism" and "proud of America", 19752009. We fit a quadratic trendline for the 1975-2001 period and use this trendline to predict article frequencies in the 2001-2009 period. The number of articles containing the phrase "proud of America" in year 2008 is 870. Examination of the articles revealed that this outlier is due to reporting on the presidential election campaign.

(a) "American Patriotism"

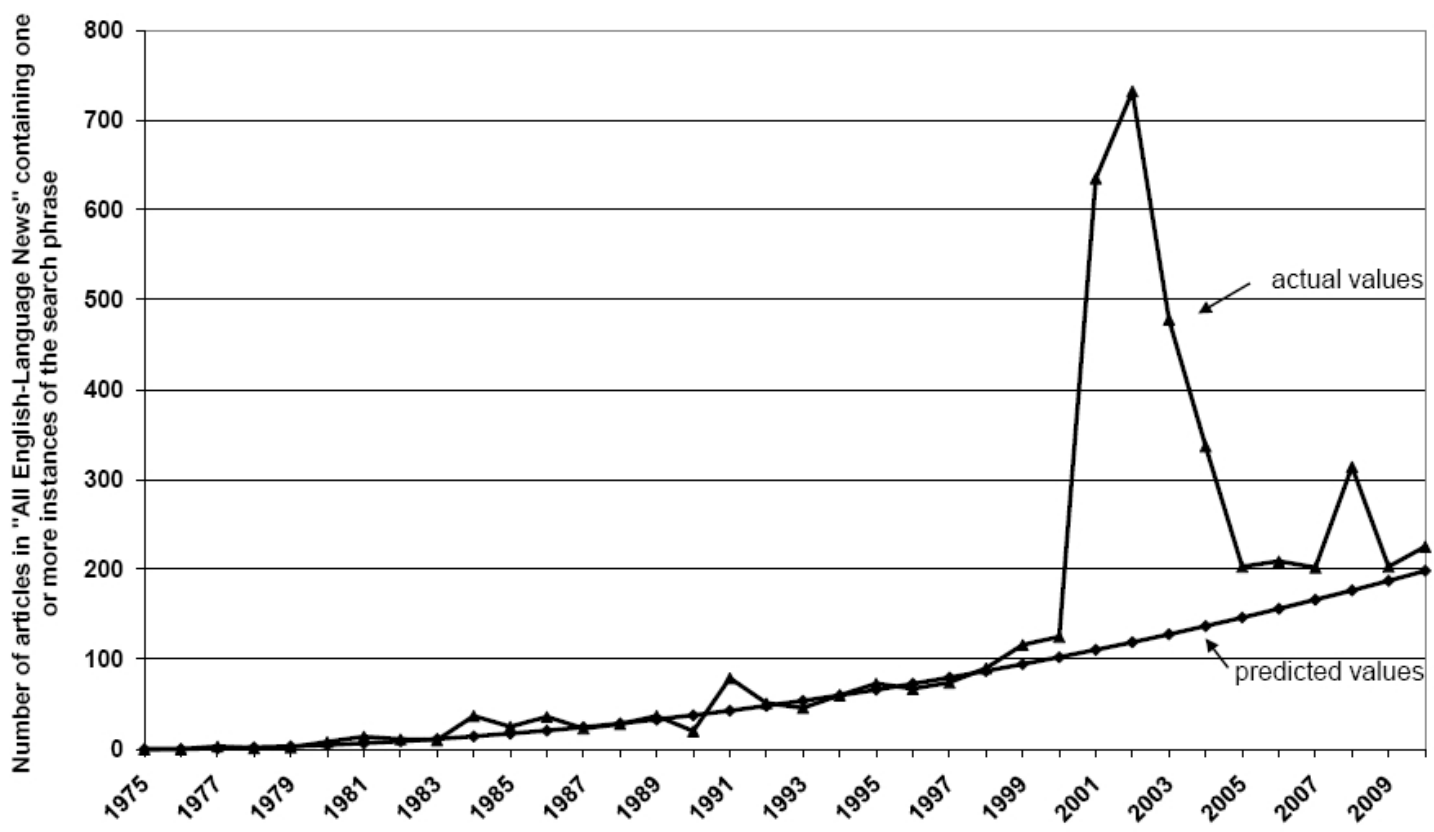

(b) "Proud of America"

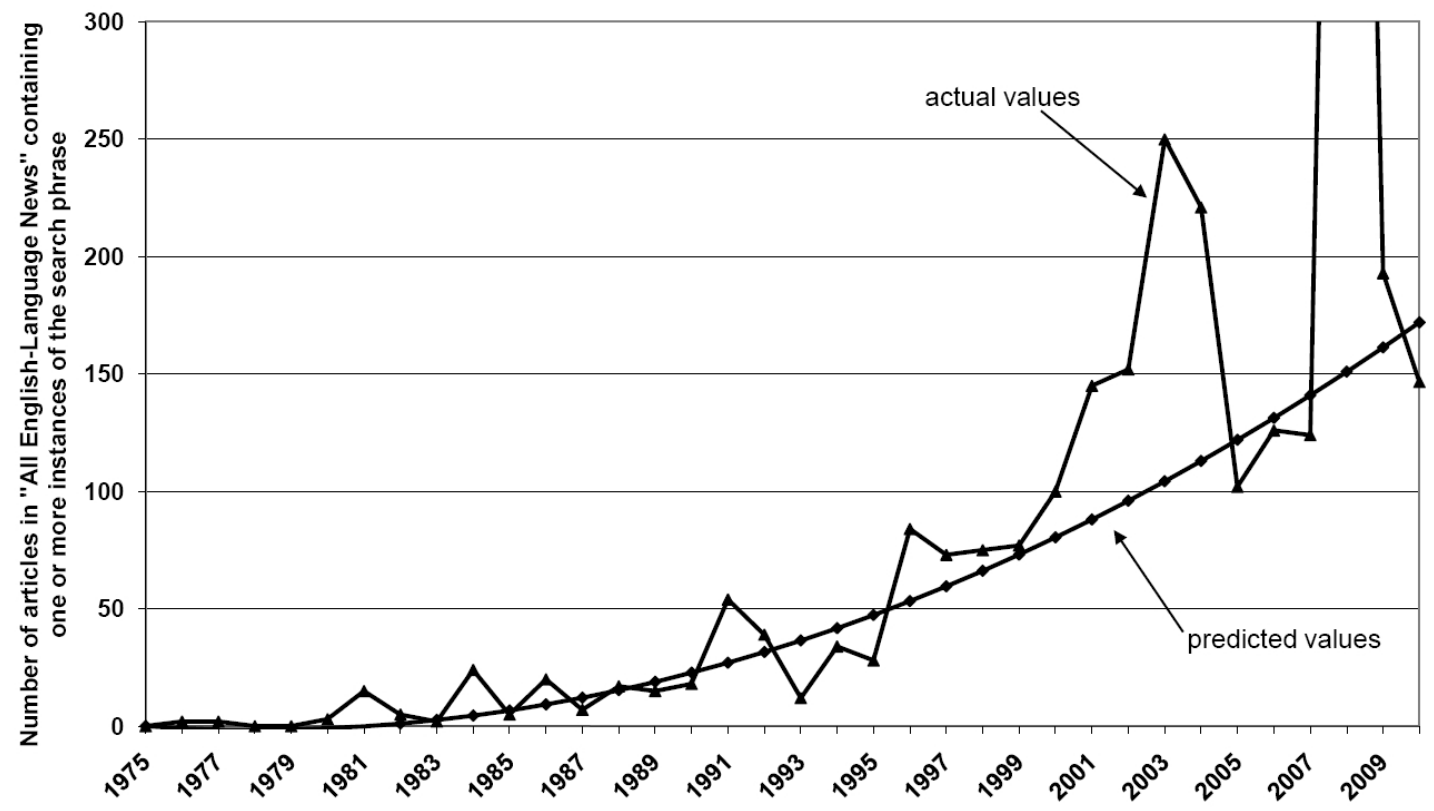


Figure 2: Cumulative abnormal returns of value and equally weighted zero investment portfolios before and after 9/11/2001 (CARs are reset to zero on day zero)

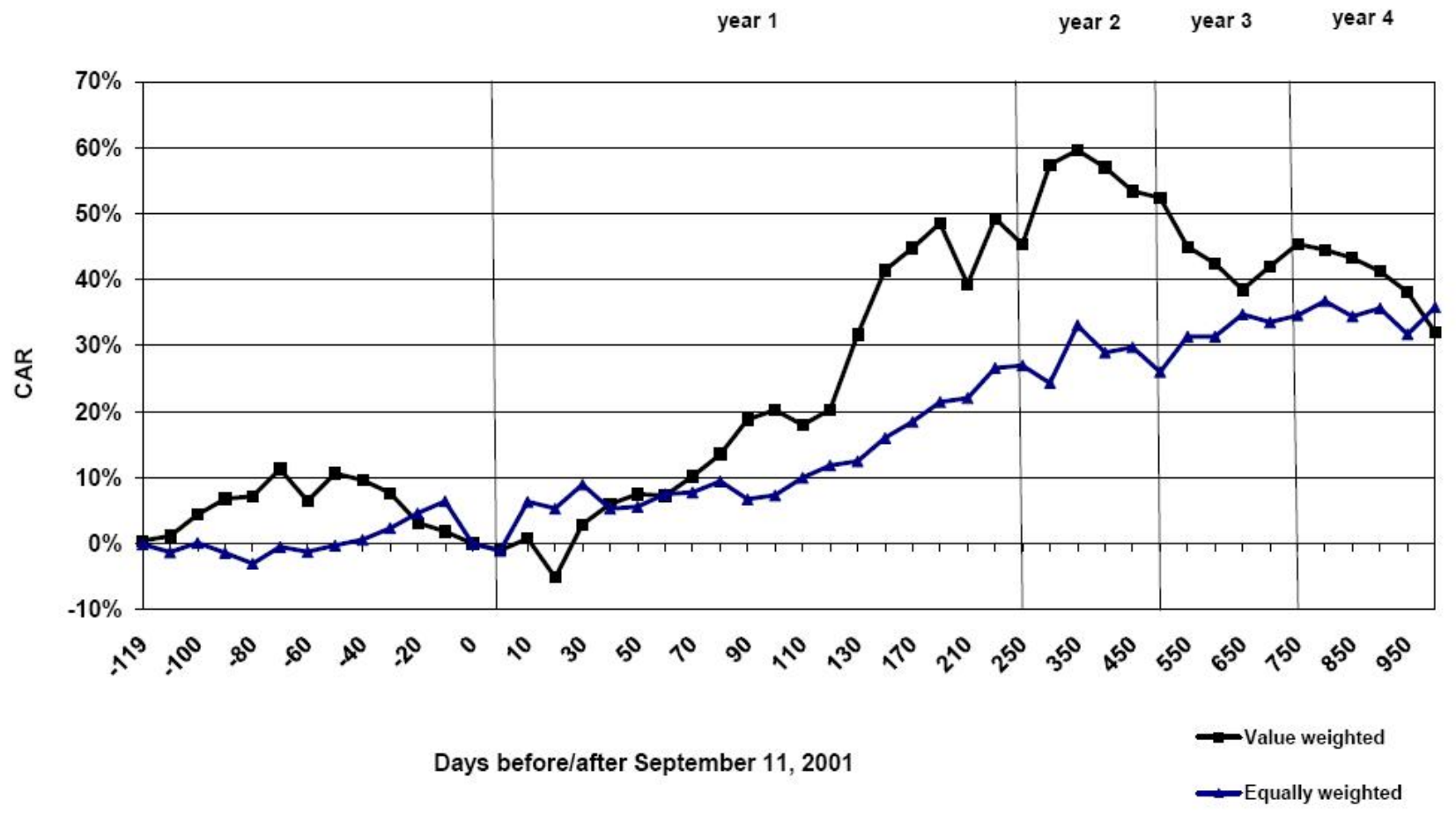

Figure 3: Cumulative abnormal returns of value and equally weighted portfolios before and after 6/6/1942 (CARs are reset to zero on day zero)

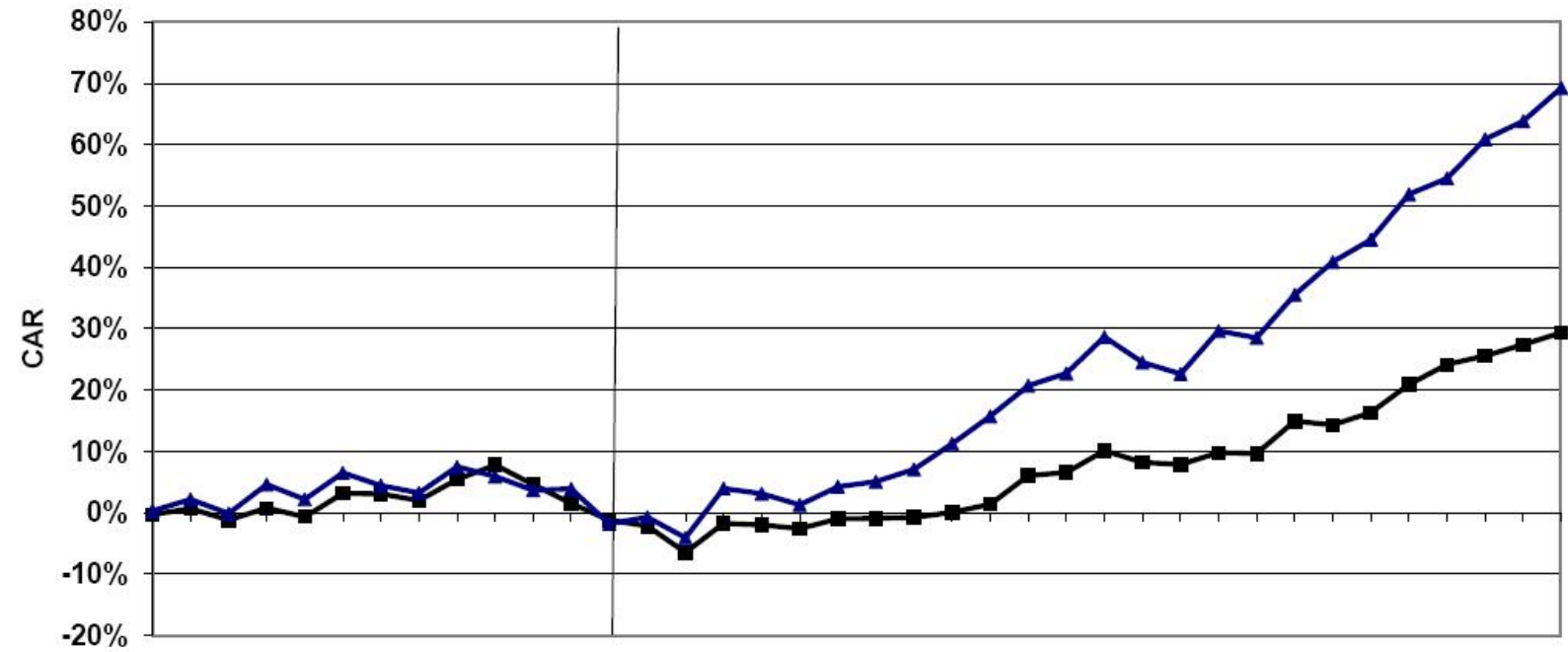

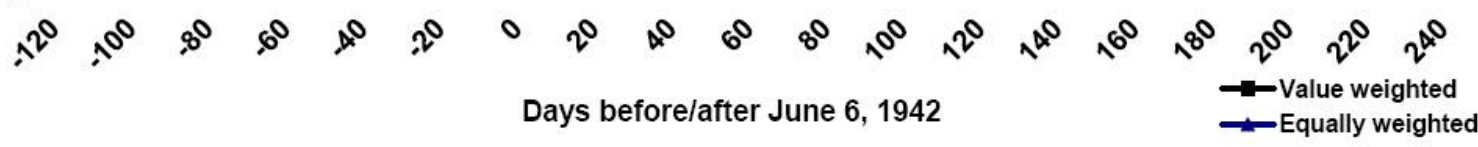


Figure 4: Cumulative abnormal returns of value and equally weighted portfolios before and after 6/23/1950 (CARs are reset to zero on day zero)

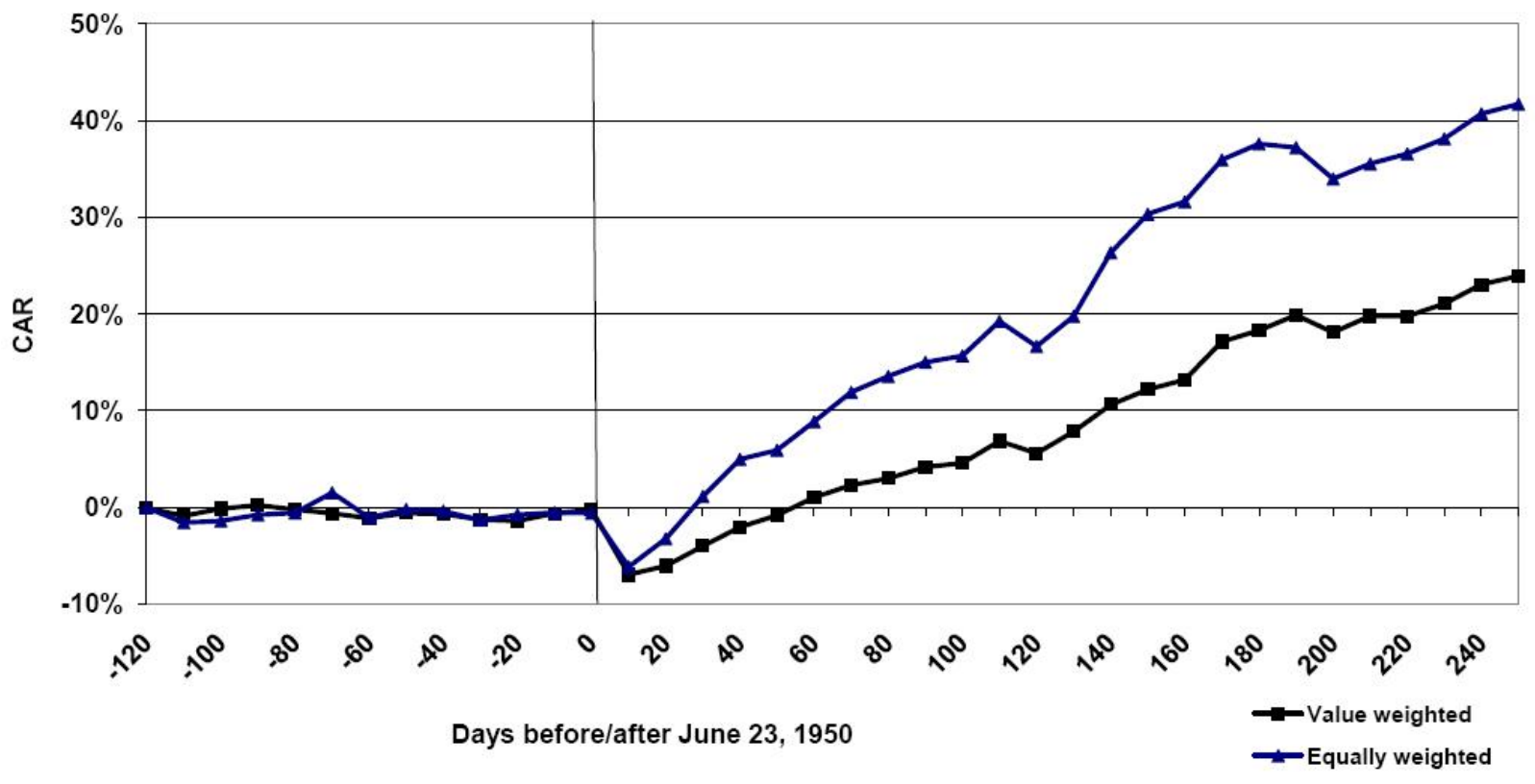

